\title{
WRF-Chem model simulations of a dust outbreak over the central Mediterranean and comparison with multi-sensor desert dust observations
}

\author{
Umberto Rizza ${ }^{1}$, Francesca Barnaba ${ }^{2}$, Mario Marcello Miglietta ${ }^{1}$, Cristina Mangia $^{1}$, Luca Di Liberto $^{2}$, \\ Davide Dionisi $^{2}$, Francesca Costabile ${ }^{2}$, Fabio Grasso ${ }^{1}$, and Gian Paolo Gobbi ${ }^{2}$ \\ ${ }^{1}$ CNR/ISAC, Unit of Lecce, Lecce, 73100, Italy \\ ${ }^{2} \mathrm{CNR} / \mathrm{ISAC}$, Unit of Rome, Rome, 00133, Italy \\ Correspondence to: Umberto Rizza (u.rizza@isac.cnr.it)
}

Received: 15 July 2016 - Published in Atmos. Chem. Phys. Discuss.: 18 July 2016

Revised: 6 December 2016 - Accepted: 11 December 2016 - Published: 3 January 2017

\begin{abstract}
In this study, the Weather Research and Forecasting model with online coupled chemistry (WRF-Chem) is applied to simulate an intense Saharan dust outbreak event that took place over the Mediterranean in May 2014. Comparison of a simulation using a physics-based desert dust emission scheme with a numerical experiment using a simplified (minimal) emission scheme is included to highlight the advantages of the former. The model was found to reproduce well the synoptic meteorological conditions driving the dust outbreak: an omega-like pressure configuration associated with a cyclogenesis in the Atlantic coasts of Spain. The model performances in reproducing the atmospheric desert dust load were evaluated using a multi-platform observational dataset of aerosol and desert dust properties, including optical properties from satellite and ground-based sun photometers and lidars, plus in situ particulate matter mass concentration (PM) data. This comparison allowed us to investigate the model ability in reproducing both the horizontal and the vertical displacement of the dust plume, as well as its evolution in time.

The comparison with satellite (MODIS-Terra) and sun photometers (AERONET) showed that the model is able to reproduce well the horizontal field of the aerosol optical depth (AOD) and its evolution in time (temporal correlation coefficient with AERONET of 0.85). On the vertical scale, the comparison with lidar data at a single site (Rome, Italy) confirms that the desert dust advection occurs in several, superimposed "pulses" as simulated by the model. Crossanalysis of the modeled AOD and desert dust emission fluxes further allowed for the source regions of the observed plumes
\end{abstract}

to be inferred. The vertical displacement of the modeled dust plume was in rather good agreement with the lidar soundings, with correlation coefficients among aerosol extinction profiles up to 1 and mean discrepancy of about $50 \%$.

The model-measurement comparison for $\mathrm{PM}_{10}$ and $\mathrm{PM}_{2.5}$ showed a good temporal matching, although it revealed a marked overestimation of $\mathrm{PM}_{10}$ and $\mathrm{PM}_{2.5}$ (of the order of $70 \%$ during the dust peak). For $\mathrm{PM}_{10}$, it was also possible to investigate the accordance between the model- and the measurement-based dust $\mathrm{PM}_{10}$, this confirming the model $\mathrm{PM}_{10}$ overestimation to be related to over-predicted dust mass up to a factor of $140 \%$. In all the model-measurement comparisons performed, the enhanced capabilities of the physics-based emission scheme with respect to its simplified, minimal version were evident and are documented.

\section{Introduction}

One of the main sources of uncertainty in our understanding of long-term climate variability is the role played by aerosols, since the related uncertainty greatly exceeds that of the other mechanisms combined all together (IPCC, 2001, 2007). Among aerosols of natural origin, mineral dust is the foremost species, comprising as much as $75 \%$ of the global aerosol mass burden, as estimated by satellite products ( $\mathrm{Gi}-$ noux et al., 2012). The role of mineral dust in the Earth system includes the interactions with other physical, chemical, and biogeochemical processes at all scales (Shao et al., 2011b). It affects the Earth's climate in many different ways, 
which are not completely understood and predictable, and influences the atmosphere-Earth balance, directly by scattering and absorbing short- and long-wave radiation with consequences for the net heating rates (e.g., Alpert and Ziv, 1989; Balkanski et al., 2007). The uncertainties in the direct radiative forcing are primarily attributed to the mineral aerosol shape (Kalashnikova and Sokolik, 2002; Haapanala et al., 2012) but also to their optical properties (Sokolik and Toon, 1999; Bi et al., 2011) and their chemical composition (e.g., Claquin et al., 1998). In addition to these direct effects, aerosol indirectly affects the radiative balance by modifying cloud properties (e.g., Rosenfeld et al., 2001; Ghan and Schwartz, 2007; Wang et al., 2010; Karydis et al., 2011; Huang et al., 2014).

It has been estimated that about half of the global total natural dust emissions are generated in the Sahara and its surroundings (Goudie, 2009; Huneeus et al., 2011; Ginoux et al., 2012; Shao et al., 2011b). Deep convection produced by the strong surface heating can uplift mineral dust particles for several kilometers into the free troposphere, where they are finally advected over large distances at the continental and intercontinental scales (Goudie and Middleton, 2001; Engelstaedter et al., 2006). Saharan dust is mainly transported along four trajectories patterns (D'Almeida, 1986; Shao, 2011b). The largest fraction (60\%) of the dust loaded from Saharan sources remains in Africa, being transported and deposited in the Sahelian countries along the well-known "meningitis belt" (Molesworth et al., 2003). Another significant fraction $(25 \%)$ is transported eastward across the Atlantic Ocean (e.g., Prospero and Mayol-Bracero, 2013; Yu et al., 2015), but a relevant (10\%) Saharan dust amount is also carried across the Mediterranean Sea to Europe (Moulin et al., 1998; Barnaba and Gobbi, 2004; Israelevich et al., 2012) in episodic storms and/or following seasonal patterns (Barnaba and Gobbi, 2004; Pey et al., 2013). The remaining $5 \%$ is transported eastward to the Middle East. During such outbreak events, mineral dust may be considered as the largest $\mathrm{PM}_{10}$ source at urban and rural sites in the Mediterranean Basin (Kaskaoutis et al., 2012; Pey et al., 2013; Salvador et al., 2014; Kabatas et al., 2014; Barnaba et al., 2017), contributing to a relevant percentage of the episodes of $\mathrm{PM}_{10}$ daily limit exceedance $\left(50 \mu \mathrm{g} \mathrm{m}^{-3}\right)$ registered at these sites (Salvador et al., 2014; Barnaba et al., 2017), with peaks of contribution up to $80 \%$ of the total mass (Kaskaoutis et al., 2012).

During the year, the transport pathway of Saharan dust towards the Mediterranean is mainly determined by lowpressure systems over the Atlantic or northern Africa, high pressure over the Mediterranean region, and/or high pressure at upper levels over Africa (Moulin et al., 1998; Barkan and Alpert, 2008; Querol et al., 2009; Pey et al., 2013; Salvador et al., 2014). Using Meteosat retrievals of dust optical depths, Moulin et al. (1998) showed that the northward transport of dust follows a seasonal pattern, being eastward when associated with the Sharav cyclones (Alpert and Ziv, 1989), and di- rected toward the western Mediterranean Basin from March to August, caused by the coupling between a Saharan low and a Libyan high or by a cyclogenesis in the Atlantic coasts of Spain.

Modeling the transport of desert dust is receiving increasing attention from the scientific community, allowing for better ascertaining its impact on radiation budget (Hsu et al., 1999), clouds (Bangert et al., 2011), air quality (Goudie and Middleton, 2001; Pey et al., 2013; Barnaba et al., 2017) and human health (e.g., Mallone et al., 2011; Stafoggia et al., 2016). Despite many improvements in characterizing dust source regions thanks to satellite products (Ginoux et al., 2012; Schepanski et al., 2012), modeling dust emission and transport is still challenging due to the high uncertainties associated with the diffuse character of the emissions, re-suspension processes, the inherent complexity of aerosol chemistry, and meteorological conditions, which strongly influence dust outbreaks and their spatiotemporal fields (e.g., Knippertz and Todd, 2012). This was evident in the intercomparison performed among 15 different global models in the framework of the global aerosol model (AeroCom) initiative (Schulz et al., 2009) as well as in a recent intercomparison study among nine European regional dust model simulations (Basart et al., 2016).

Aim of this study is to evaluate the capability of the WRFChem model using a physically based desert dust emission scheme to properly simulate an episode of mineral dust longrange transport occurred over the central Mediterranean in May 2014. This aim is pursued taking advantage of the operational aerosol and dust observations available from satellite and AERONET (Aerosol Robotic Network) sun photometers (Holben et al., 1998) plus additional ground-based observations carried on in central Italy within the EC-LIFE+ DIAPASON project (Gobbi et al., 2017; Struckmeier et al., 2016; Barnaba et al., 2017). The desert dust event actually consisted of a series of dust plumes generated in the northwestern Sahara by strong winds associated with an omega-like circulation, characterized by a low-pressure system localized in the Atlantic coasts of Spain. Dust plumes were transported northward, resulting in an intense dust event over the Mediterranean (aerosol optical depth, AOD, at $550 \mathrm{~nm}>1$ ) impacting mostly Italian and French sites, with maximum desert dust loads between 21 and 23 May 2014.

A preliminary study by Rizza et al. (2016) used WRFChem with a dust emission scheme based on a semiempirical dependence between the horizontal and the vertical dust fluxes (Marticorena and Bergametti, 1995), highlighting a large over-prediction of the AOD dust outbreak over Europe. In this work we test the use of a more advanced physicsbased dust emission scheme proposed by Shao (2001, hereinafter denoted S01), which explicitly considers the two major emission mechanisms for mineral dust, namely the saltation bombardment (Marticorena and Bergametti, 1995) and the aggregate disintegration, and a refined four-classes texture soil type. To provide further insight into the advantages 
of the $\mathrm{S} 01$ scheme, in this study we also make a comparison with the model outcomes using its "minimal" version (described by Shao et al., 2011a, and referred to as S11 in the following), in which the dust emission is independent of the sand particle size (results of this additional "sensitivity" test are included in Appendix A).

The outline of the work is as follows. The setup of the WRF-Chem model used here is described in Sect. 2. Data and methods used for the comparison with meteorological and aerosol fields are described in Sect. 3. Results are shown and discussed in Sect. 4, in which we evaluate first the ability of the WRF-Chem model in reproducing the synoptic situation (Sect. 4.1) and then the dust field in the horizontal (Sect. 4.2) and vertical (Sect. 4.3) scale exploiting the multisensor aerosol and desert dust observational dataset. Concluding remarks appear in Sect. 5.

\section{The WRF-Chem model}

WRF-Chem is a fully coupled online community model for the prediction and simulation of weather, dispersion, air quality, and regional climate (Grell et al., 2005). The chemistry model has been built to be consistent with the Weather Research and Forecasting (WRF, http://www2.mmm.ucar.edu/ wrf/users/) modeling package. Possible applications of the current modeling system concern (i) the prediction and simulation of weather, or regional and local climate; (ii) the release and transport of constituents through coupled weather prediction/dispersion model simulations; (iii) the analysis of the full interaction of chemical species as well as particulate matter through a coupled weather-dispersion-air quality model; and (iv) the study of processes that are important for global climate change issues, including the aerosol direct and indirect forcing.

\subsection{Model setup}

In this study the WRF-Chem version 3.6.1 was used. Figure 1 shows the model domain, which covers northern Africa, southern Europe, and the western part of Asia, with $160 \times 90$ grid points centered at $30.6^{\circ} \mathrm{N}, 18.7^{\circ} \mathrm{E}$. In the same figure the location of the six AERONET stations used in the analysis is reported. The horizontal grid spacing is $50 \mathrm{~km}$ for both directions with 40 vertical levels up to $50 \mathrm{hPa}$. The simulation lasted 10 days, starting on 16 May, 00:00 UTC. Boundary and initial conditions were extracted from NCAR/NCEP Final Analysis (FNL from GFS) (ds083.2), with $1^{\circ}$ resolution, available every $6 \mathrm{~h}$. An idealized vertical profile for each chemical species is provided to start the model simulation. This vertical profile is based upon northern hemispheric, midlatitude, clean environment conditions.

\subsubsection{Physical parameterizations}

As summarized in Table 1, the following physical schemes are used. The Mellor-Yamada-Nakanishi and $\mathrm{Ni}$ ino (MYNN) level 2.5 turbulent kinetic energy (TKE) parameterization is used to describe the planetary boundary layer (Nakanishi and Niino, 2009). The MM5 similarity scheme (Paulson, 1970) and the RUC land surface model (Benjamin et al., 2004) are chosen to represent the surface layer physics and the land surface interaction. The Rapid Radiative Transfer Model (RRTMG) for both shortwave (ra_sw_physics $=4$ ) and long-wave (ra_lw_physics $=4$ ) radiation is used for the aerosol direct radiative effect (Mlawer et al., 1997). The Purdue Lin scheme (mp_physics =2) is used for the treatment of the microphysics processes, with all parameterization production terms based on Lin et al. (1983) and Rutledge and Hobbs (1984), with some modifications, including saturation adjustment following Tao et al. (1989) and ice sedimentation. This setup is compatible with the shortwave radiative feedbacks (or what is known as the "direct effect"), which are included with the chemistry.

\subsubsection{Aerosol-related model settings}

As an aerosol/chemistry module, the GOCART scheme (Giorgia Tech/Goddard Global Ozone Chemistry Aerosol Radiation and Transport model; Chin et al., 2000) was selected (chem_opt $\left.=G O C A R T \_S I M P L E\right)$. It produces output for seven bulk aerosol species - organic carbon (OC1, OC2), black carbon (BC1, BC2), other GOCART primary species $\left(\mathrm{PM}_{2.5}, \mathrm{PM}_{10}\right)$ and sulfate (only secondary aerosol species) - and for eight sectional aerosols species: four dust bins ( 0 $2.5,2.5-5,5-10,10-20 \mu \mathrm{m})$ and four sea salt bins $(0.1-0.5$, $0.5-1.5,1.5-5,5-10 \mu \mathrm{m})$. GOCART comes with simple sulfur gas phase chemistry including dimethylsulfide (DMS) and sulfur dioxide $\left(\mathrm{SO}_{2}\right)$. While dust and sea salt emissions are surface wind speed dependent, the others are prescribed from emission inventories. In this context, the threedimensional background fields for $\mathrm{OH}, \mathrm{H}_{2} \mathrm{O}_{2}$, and $\mathrm{NO}_{3}$; the two-dimensional background fields for dimethylsulfide (DMS); and emission fields for organic carbon (OC), black carbon (BC), sulfur dioxide $\left(\mathrm{SO}_{2}\right)$, and particulate matter (PM) are obtained from the PREP-CHEM-SRC emission preprocessor package (Freitas et al., 2011). This preprocessor reads the global anthropogenic emissions from the RETRO reanalysis (http://retro.enes.org) and EDGAR (http://edgar. jrc.ec.europa.eu) emission database and the GOCART static background fields. These fields are provided to the program convert_emission (included in WRF-Chem public release) to produce the gridded netCDF emission files for the WRFChem domain.

Aerosol optical properties are derived using the MaxwellGarnett mixing rule (aer_op_opt $=2$ within the model configuration; see Table 1) in its approximate parameterization, 


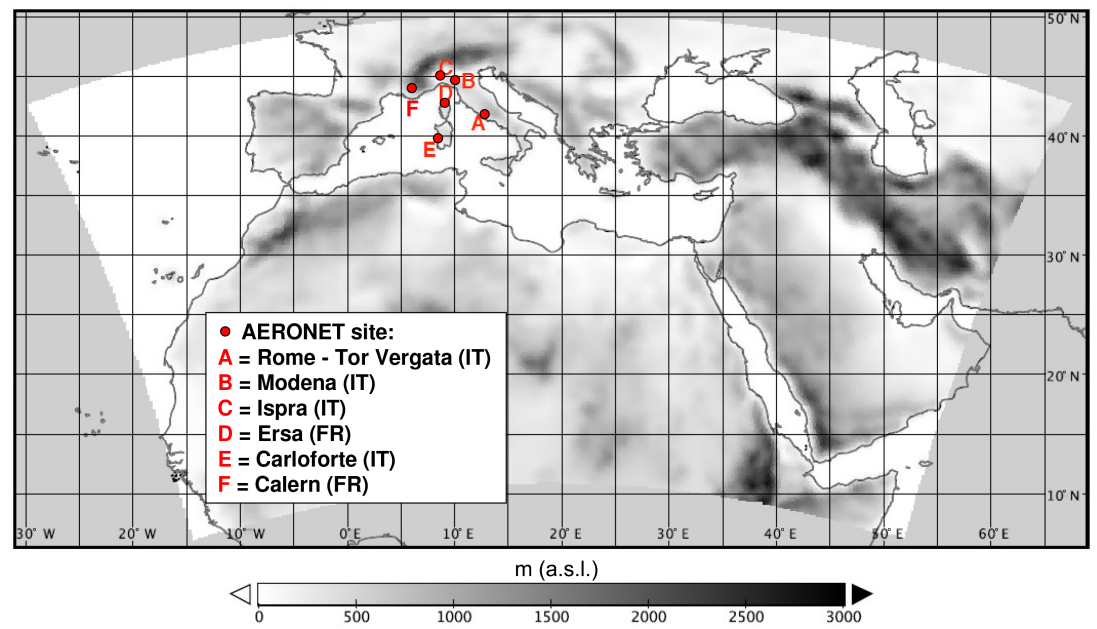

Figure 1. The numerical domain/topography and location of the AERONET stations used in this study.

Table 1. Namelist settings of the physical parameterizations used in the WRF-Chem setup.

\begin{tabular}{lrll}
\hline & $\begin{array}{r}\text { Option } \\
\text { number }\end{array}$ & Namelist variable & Model \\
\hline Land surface & 3 & sf_surface_physics & RUC model \\
PBL model & 5 & bl_pbl_physics & MYNN level 2.5 \\
Surface similarity & 1 & sf_sfclay_physics & MM5 similarity scheme \\
Microphysics & 2 & mp_physics & Purdue Lin \\
Shortwave radiation & 4 & ra_sw_physics & RRTMG \\
Long-wave radiation & 4 & ra_lw_physics & RRTMG \\
Aerosol mixing rules & 2 & aer_op_opt & Maxwell-Garnett \\
\hline
\end{tabular}

which considers small spherical randomly distributed black carbon cores in a particle (Bohren and Huffman, 1983).

Aerosol removal processes include both dry and wet deposition. In particular, a dry deposition scheme accounting for gravitational settling and surface deposition is used (Wesely, 1989) to simulate the dry removal of desert dust, while a simple wet deposition scheme that considers rainout/washout in large-scale precipitation (Balkanski et al., 1993) is used for both sea-spray and desert dust aerosols (Su and Fung, 2015). Note that, in this scheme, only non-parameterized (resolved) precipitation is active in the aerosol removal.

\subsubsection{Dust emission parameterization}

In any dust emission model, the basic parameters to be considered are (1) the threshold friction velocity at which dust particles begin to move and (2) the horizontal and vertical sand dust fluxes. The emission of dust particles can be classified considering the wind conditions at the surface. In particular, under strong wind conditions the surface wind shear is the principal dynamic parameter and the dust emission is generally a function of the threshold friction velocity (see further details in Sect. 4.2). Under these conditions two main dust emission mechanisms have been recognized: saltation bombardment (Marticorena and Bergametti, 1995) and aggregate disintegration (Shao, 2001). Another important mechanism is the direct aerodynamic lifting (Klose and Shao, 2012), which is effective when the lower troposphere is in the free-convective regime.

The WRF-Chem model (version 3.6.1) includes three alternative packages for mineral dust emission, two from the GOCART model ("DUST-GOCART" and "DUSTGOCART/AFWA") and a third ("DUSTUOC") from the University of Cologne. This latter is further divided into three emission parameterizations with a progressive level of simplification (Shao, 2001, 2004; Shao et al., 2011a). A preliminary comparison between the DUST-GOCART/AFWA and the DUSTUOC-Shao (2001) (S01) schemes is discussed in Rizza et al. (2016), showing that the GOCART/AFWA emission scheme produces an important over-prediction of the dust concentration. This is also in agreement with recent findings by Fountoukis et al. (2016). This may in part be explained by the fact that the AFWA scheme considers vertical dust flux only related to the clay content, while the S01 scheme considers a more realistic soil texture type.

In this work we have therefore opted for the S01 scheme and tested its performances in comparison to observations. 
Table 2. Namelist settings of the chemical and dust emission parameterization used in the WRF-Chem setup.

\begin{tabular}{lrrl}
\hline Namelist variable & S01 & S11 & registry.chem package \\
\hline chem_opt & 300 & 300 & GOCART_SIMPLE \\
dust_opt & 4 & 4 & dustuoc \\
dust_schemes & 1 & 3 & shao_2001 - shao_2011
\end{tabular}

As mentioned above, results from the "minimal" version of DUSTUOC (Shao et al., 2011a, here S11) are also included in the Appendix A of the present study to highlight the advantages of the S01 scheme. In S11, the size distribution of the airborne sand and dust particles is only constrained by the minimally disturbed particles size distribution. The expression "minimally disturbed" refers to the case in which the disturbance is so weak that the disintegration of aggregates almost does not occur (Shao, 2004).

Both S01 and S11 are based on a dust emission parameterization that considers explicitly the two major dust emission mechanisms described above. In particular, the aggregate disintegration is modeled following the hypothesis that dust aggregates fragment as they hit the surface. Both schemes may be considered as spectral emission schemes, because they are based on a size-resolved dust emission equation by supposing that particles are divided into $n=4$ particle size intervals. In both cases the total dust flux $(F)$ is expressed as an integral of the dust emission rate for particles of size $d_{i}$ by saltation of particles of size $d_{\mathrm{s}}$ :

$F=\int_{d_{i}}^{d_{s}} \int_{0}^{d_{i}} f\left(d_{i}, d_{s}\right) p\left(d_{i}\right) p\left(d_{s}\right) \delta d_{i} \delta d_{s}$,

where $f\left(d_{i}, d_{s}\right)$ is the dust emission rate for particles of size $d_{i}$ generated by the saltation of particles of size $d_{s}$. The difference between the S01 and S11 schemes is in the way the dust emission rate is calculated (see Eq. 52 of S01 and Eq. 34 of S11). The quantity $p\left(d_{i, s}\right)$ can be regarded as a combination of two idealized particle size distributions, known as minimally disturbed particle size distribution, $p_{\mathrm{m}}\left(d_{i, s}\right)$, and fully disturbed particle size distribution, $p_{\mathrm{f}}\left(d_{i, s}\right)$, whose values are provided in a look-up table for each soil category. As $p_{\mathrm{m}}$ and $p_{\mathrm{f}}$ are functions of land surface properties, the soil data used in WRF-Chem play an important role in dust emission simulation. In this study, the default soil categorization data set from the United States Geological Survey (USGS) with 5 arcmin geographic resolution was selected. The effective soil texture is obtained from the USGS 12 classes considering only four types classes, namely sand, sandy clay loam, loam, and clay. More details of this formulation can be found in Shao (2001), Shao et al. (2011a), Kang et al. (2011), and Su and Fung (2015). The chemistry and dust emission parameterizations adopted here are reported in Table 2.

\section{Observational dataset}

\subsection{Meteorological fields from NCEP/NCAR}

Geopotential height maps at 500, 700, and $850 \mathrm{hPa}$ are obtained using the daily mean composites of the NCEP/NCAR (National Centers for Environmental Prediction/National Center for Atmospheric Research) reanalysis (Kalnay et al., 1996). Composites (averages) of the daily-mean variables over several days are created from the NCEP/NCAR Reanalysis (http://www.esrl.noaa.gov/psd/data/).

\subsection{Aerosol horizontal field}

The observation-based characterization of the aerosol field over the horizontal scale is made here by using both a network of sun photometers located at multiple sites and measuring synchronously and satellite retrievals capturing wider areas within a single passage. In particular, AERONET sun photometers (Holben et al., 1998) operating at central Mediterranean sites are used to evaluate the columnar aerosol content over the investigated area. These measurements are complemented by the aerosol retrievals from the MODIS sensors on board the NASA platform Terra.

\subsubsection{AERONET AOD dataset}

AERONET is a federation of ground-based sun photometers established by the USA NASA and currently led by NASA and the French CNRS. It includes nearly 1000 sun photometers (CIMEL ${ }^{\circledR}$ ) spread worldwide, whose data are processed following the same aerosol retrieval procedures (Dubovik and King, 2000; Dubovik et al., 2000, 2006) and made available in quasi-real time through a dedicated NASA portal (http://aeronet.gsfc.nasa.gov).

The main quantity measured by sun photometers is the aerosol optical depth (AOD), an optical parameter quantifying the aerosol load in the whole atmospheric column. The AOD is unitless, and represents the integral over altitude of the aerosol extinction coefficient (units of length ${ }^{-1}$ ).

In this study we use level 2 (L2, i.e., cloud-screened and quality-assured) AOD measurements in the visible spectrum performed at those stations localized in the central Mediterranean fulfilling the following requirements: (i) consistence with the spatial pattern of the dust intrusion, i.e., location within the area affected by the investigated dust outbreak and (ii) availability of L2 data in the period considered. The resulting six stations are shown in Fig. 1 and include the AERONET sites of Ersa (Corsica, France; $9.359^{\circ} \mathrm{E}, 43.004^{\circ} \mathrm{N} ; 80 \mathrm{~m}$ elevation), Calern (France; $6.927^{\circ} \mathrm{E}, 43.749^{\circ} \mathrm{N} ; 1270 \mathrm{~m}$ elevation), Carloforte (Sardinia, Italy; $8.310^{\circ} \mathrm{E}, 39.140^{\circ} \mathrm{N} ; 15 \mathrm{~m}$ elevation), Rome (Italy; $12.647^{\circ} \mathrm{E}, 41.840^{\circ} \mathrm{N} ; 130 \mathrm{~m}$ elevation), Modena (Italy; $10.945^{\circ} \mathrm{E}, 44.632^{\circ} \mathrm{N} ; 56 \mathrm{~m}$ elevation), and Ispra (Italy; $8.627^{\circ} \mathrm{E}, 45.803^{\circ} \mathrm{N} ; 235 \mathrm{~m}$ elevation). The uncertainty in AOD measurements from the CIMEL field sun 
photometers is mainly due to calibration uncertainty. Eck et al. (1999) estimated this to be $\sim 0.01$ in the visible and near IR, increasing to $\sim 0.02$ in the ultraviolet. Here the AERONET AOD at $550 \mathrm{~nm}$ is used.

\subsubsection{MODIS AOD dataset}

The MODerate-resolution Imaging Spectroradiometer (MODIS; Salomonson et al., 1989) instrument has flown on board the NASA Terra and Aqua spacecraft since December 1999 and May 2002, respectively. It has 36 wavelength bands spanning from the visible to the infrared, high spatial resolution, and near-daily global coverage. Terra, whose data are used here, overpasses the Equator at 10:30 LT. Aerosol characterization was and currently is a core MODIS mission (Kaufman et al., 1997) and the AOD is still the most robust aerosol physical parameter derived from space. Two different approaches are used to retrieve the AOD from MODIS data. These are commonly referred to as "Dark Target" (DT; Kaufman et al., 1997) and "Deep Blue" (DB; Hsu et al., 2004). The algorithm at the basis of the DT approach is further differentiated when applied over ocean (Remer et al., 2005) or land (Levy et al., 2007a, b), and it is not suitable to be applied over bright surfaces (deserts, snow, sun glint). The DB approach was developed to fill this gap (Hsu et al., 2004) and well complements the DT retrievals. The most recent collection (C006) of MODIS AOD data provides a single AOD product combining both the DT and the DB AOD retrievals and, as it is considered the "best-of" product for most quantitative purposes (Levy et al., 2013), it was used in our study (in particular here we use the MODIS daily product MOD08_D3 v6).

\subsection{Aerosol altitude-resolved view over Rome (Italy)}

The characterization of the aerosol field over the vertical scale is made here employing continuous (h24, i.e., $24 \mathrm{~h}$ a day, 7 days a week) lidar/ceilometer measurements performed in the CNR-ISAC Rome Atmospheric Supersite (CIRAS) in Rome-Tor Vergata, which hosts one of the six AERONET sites considered in this study (point A in Fig. 1). The site is frequently affected by Saharan dust (e.g., Gobbi et al., 2004, 2013) and lies just in the middle of the area impacted by the desert dust event under examination (Gobbi et al., 2017; Barnaba et al., 2017). The Rome-Tor Vergata lidar and ceilometer measurements are therefore used here to evaluate the model capability to reproduce the dust plume vertical structure and its transport timing, as well as to provide further insight into the model-measurement AOD comparison.

In May 2014, the lidar and ceilometer measurements at CIRAS were part of a larger set of aerosol observations performed in the framework of the EC-LIFE+ project DIAPASON ("Desert-dust impact on air quality through model predictions and advanced sensors observations", http://www. diapason-life.eu; more details on the project and relevant results can be found in Gobbi et al., 2017; Barnaba et al., 2017; Struckmeier et al., 2016). Lidar/ceilometer instruments characteristics and relevant dataset used in this study are described hereafter.

\subsubsection{Lidar datasets}

The aerosol vertical profiles were collected by two different colocated instruments: a commercial CHM15K ceilometer (Lufft Mess- und Regeltechnik GmbH, http://www.lufft. com), and a research-type lidar (ATLAS) developed at the ISAC-CNR laboratories. The former is now part of an underdevelopment Italian network of such systems (the Automated Lidar-Ceilometer Network, ALICENET, http://www. alice-net.eu), which are already widely employed in Germany, where the national meteorological service (DWD) operates over 50 of these instruments (e.g., Flentje et al., 2010a, b; Wiegner and Geiß, 2012). The CHM15K instrument uses a pulsed $\mathrm{Nd}$ :Yag laser source at $1064 \mathrm{~nm}$ with an output laser energy of about $8 \mu \mathrm{J}$, a pulse repetition rate of $5-7 \mathrm{kHz}$ and a vertical resolution of $15 \mathrm{~m}$. Its configuration allows for sounding of the aerosol load in the atmosphere in the range $150 \mathrm{~m}-15 \mathrm{~km}$. As for all lidar systems, the signal in the lowermost atmospheric levels has to be corrected due to the incomplete superposition of the laser and the receiver field of view (FOV). For this system the overlapping correction function is provided by the manufacturer, which determines the correction in the factory using a reference instrument.

The ATLAS system is a further miniaturization of a previous mobile, polarization-sensitive lidar system (VELIS) developed by ISAC-CNR (Gobbi et al., 2000). ATLAS maintains most of the VELIS characteristics, although it uses a different $1 \mathrm{kHz}, 30 \mu \mathrm{J}$ pulse $^{-1}$ laser source and reaches full overlap at approximately $500 \mathrm{~m}$. As VELIS, ATLAS has two receiving channels, collecting respectively the light backscattered by particles in the parallel and perpendicular polarization planes with respect to the laser-emitted one. Since spherical particles do not change the polarization plane of the incident light, while non-spherical particles do, the comparison of the two lidar channels allows for the presence of nonspherical aerosols (as mineral particles) to be detected in the atmosphere (e.g., Gobbi, 1998). An example of this capability is provided in Sect. 4.3.

Both the CHM15K and ATLAS are able to work unattended in continuous mode (h24), and their measurements are therefore used here to investigate the capability of the model to reproduce the dust plumes over Rome in terms of both temporal matching and vertical extent. In particular, we use both the (qualitative) range-corrected lidar signal (RCS), to a first approximation related to the aerosol amounts, and the (quantitative) aerosol extinction profiles from ATLAS (see Sect. 4.3). The inversion of the lidar RCS into aerosol optical properties (aerosol backscatter and extinction coefficients, $\beta_{\mathrm{a}}$ and $\alpha_{\mathrm{a}}$, respectively) requires the 
employment of the backward solution of the Klett inversion algorithm (Klett, 1981) to the data. In addition to the estimation of the molecular backscatter and extinction coefficients ( $\beta_{\mathrm{m}}$ and $\alpha_{\mathrm{m}}$, respectively, calculated from climatological monthly air density profiles), the solution requires two assumptions: a boundary value at a reference height $z_{0}$ where $\beta_{\mathrm{a}}\left(z_{0}\right)=0$ (Rayleigh calibration) and a so-called "lidar ratio" $\left(S_{\mathrm{a}}=\alpha_{\mathrm{a}} / \beta_{\mathrm{a}}\right)$. In our case, a calibration constant was derived applying the Rayleigh calibration to nighttime and cloud-free signals averaged over $1 \mathrm{~h}$ at $75 \mathrm{~m}$ height resolutions. For the second assumption, we used an approach based on numerical simulations of aerosol scattering (e.g., Barnaba and Gobbi, 2001; Barnaba et al., 2004), and widely validated elsewhere (Gobbi et al., 2003; Barnaba et al., 2004). In particular, in this study $\alpha_{\mathrm{a}}$ is computed using a functional relationship $\alpha_{\mathrm{a}}=\alpha_{\mathrm{a}}\left(\beta_{\mathrm{a}}\right)$ derived by Barnaba and Gobbi (2001) assuming non-spherical desert dust particles. The expected error on $\alpha_{\mathrm{a}}$ is of the order of $30 \%$. This approach requires an iterative inversion technique to correct the backscatter signal for extinction losses until convergence in the integrated aerosol backscatter $\left(\mathrm{IAB}=\sum_{0}^{\mathrm{zcal}} \beta_{\mathrm{a}}(z)\right)$ is reached. The estimation of the aerosol extinction coefficient at altitudes below complete superposition of the laser and telescope FOV is obtained from a linear fit of the first two valid lidar points.

\subsubsection{In situ $\mathbf{P M}_{10}$ data}

To complement the column-integrated and the vertically resolved aerosol optical properties described above, for the Rome site the observational dataset used to test the model also includes the standard particulate matter (PM) metrics regulated by the EU Air Quality legislation (i.e., the daily average $\mathrm{PM}_{10}$ and $\mathrm{PM}_{2.5}$ data). In this case hourly resolved measurements at the Rome-Castel di Guido site (about $15 \mathrm{~km}$ west of the city center) were used. These were collected using a SWAM dual-channel instrument (FAI, Italy, http://www.fai-instruments.com/index.php/en/ products-eng/swam-dual-channel-eng, last access: 23 December 2016), providing mass concentration measurement on an hourly basis thanks to a specific application of $\beta$ technology including information about atmospheric mixing ratio. Relevant results are provided in Sect. "Comparison to ground-level PM values".

\section{Results and discussion}

\subsection{Model capability to correctly reproduce the meteorology driving and associated with the dust event}

Several authors have evidenced that the northward dust transport pathway from the Sahara follows a seasonal pattern, changing from the eastern to the western Mediterranean Basin during spring and summer (Moulin et al., 1998; Barnaba and Gobbi, 2004; Engelstaedter et al., 2006).
As "case study" representative of the springtime conditions, an intense dust episode affecting the central Mediterranean between 19 and 24 May 2014 was selected. This case corresponds to one of three different major cyclogenesis situations that are thought to be responsible for the northward transport of Saharan dust toward the Mediterranean (e.g., Engelstaedter et al., 2006), which is the cyclogenesis in the Atlantic coasts of Spain.

The synoptic analysis of the dust event is described using the NCEP/NCAR reanalysis (Kalnay et al., 1996). In Fig. 2 we show the geopotential height in the middle $(500 \mathrm{hPa})$ and lower $(850 \mathrm{hPa})$ troposphere averaged in different subperiods within 16-25 May 2014. The $500 \mathrm{hPa}$ geopotential height maps show for the first three days (16-18 May) an intense zonal flow in the southern Mediterranean (Fig. 2a) as a consequence of a pressure low centered over the Balkan area and a high-pressure system over northeastern Africa. The following days (19-24 May) are characterized by an omega-like circulation, which is consequence of the northward expansion of the ridge toward the central Mediterranean and of the intensification of a pressure minimum over Spain, which is responsible for (i) strong westerly winds in the northern Sahara and (ii) southwesterly flow over the western Mediterranean (Fig. 2b). During the last simulated day (25 May) we have a further rotation of wind, which blows from westsouthwest (not shown).

At lower levels $(850 \mathrm{hPa})$, the reanalysis maps for the period 16-22 May show the presence of a high-pressure system over Libya and Egypt and of a low over Spain and Morocco that intensifies the southerly wind in the western Mediterranean (Fig. 2c). From 22 to 24 May, the low pressure moves eastward and northward, producing a clockwise rotation of the low-level wind, blowing from west-southwest over the western Mediterranean (Fig. 2d). A high-pressure system of limited extension elongated from Libya northward determines southerly currents confined over southern Italy.

The ability of the model to reproduce the meteorology driving and associated with the dust event is evaluated in terms of geopotential height (Fig. 3) during selected dates (21, 22, and 23 May). The geopotential field is obtained from the reanalysis at $700 \mathrm{hPa}$ (panels a, c, e, in Fig. 3) and compared to the corresponding WRF-Chem simulations (panels b, d, f) for the three selected dates. This quantity is important because the geopotential at $700 \mathrm{hPa}$ gives an indication of the circulation pattern associated with the dust transport in the low to middle troposphere.

Figure 3a shows a low pressure over the Atlantic coasts of Spain on 21 May and a ridge extending from northern Africa to the central Mediterranean. Together with a low over Turkey, the whole pattern resembles an omega-like configuration, responsible for southwesterly wind over the western Mediterranean. On 22 May, the ridge is still persistent over the Italian Peninsula and responsible for the southwesterly wind over the western Mediterranean, which brings air of African origin toward northern and central Italy and south- 

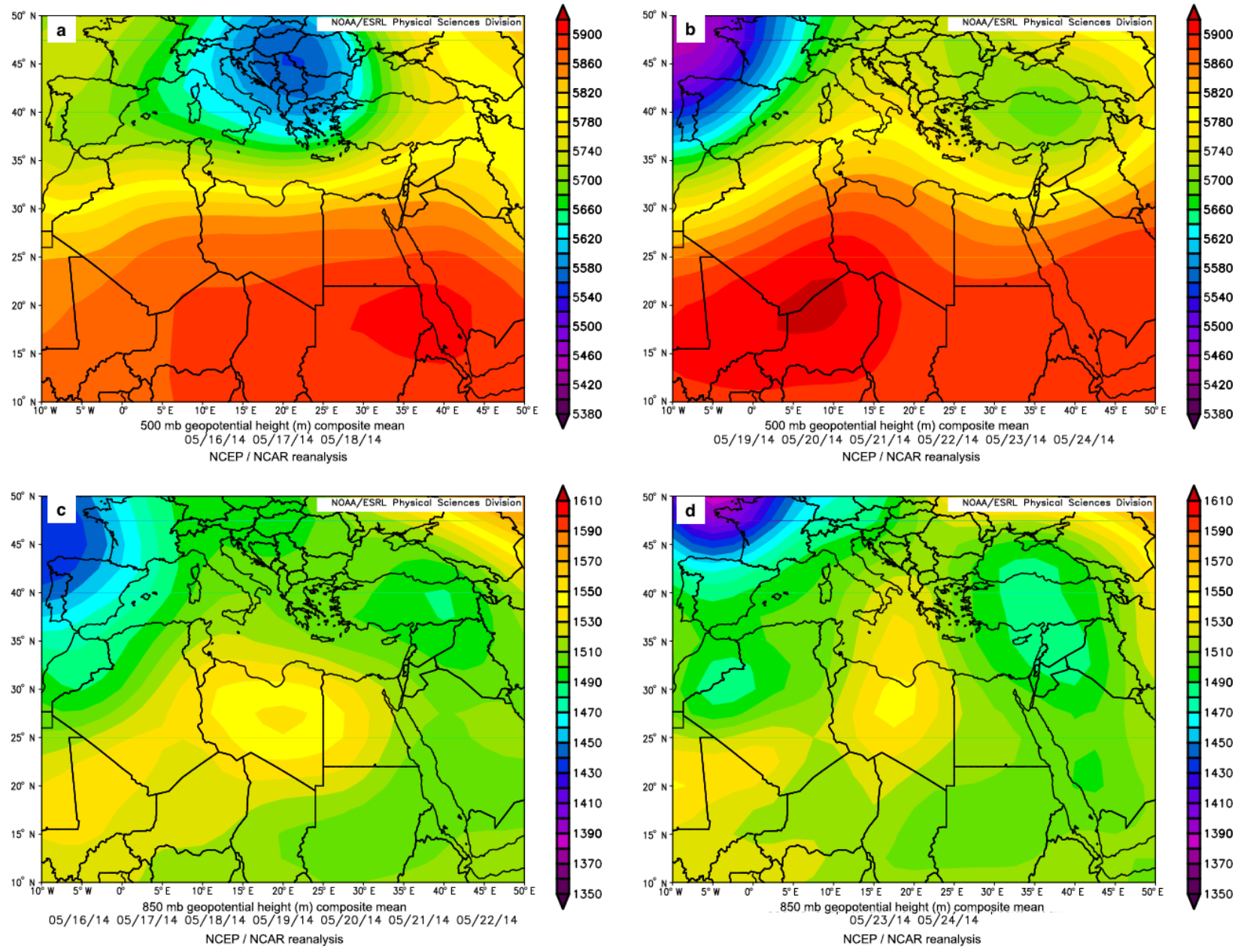

Figure 2. Time averaged maps of geopotential height obtained using the NCEP/NCAR Reanalysis over the periods (a) 16 to 18 May 2014 at $500 \mathrm{hPa}$, (b) 19 to $24 \mathrm{May} 2014$ at $500 \mathrm{hPa}$, (c) 16 to $22 \mathrm{May} 2014$ at $850 \mathrm{hPa}$, and (d) 23 to $24 \mathrm{May} 2014$ at $850 \mathrm{hPa}$.

ern France (Fig. 3b). On 23 May, the progressive weakening of the ridge (that at the end of the period is confined over the southern part of the central Mediterranean) and the northward movement of the low over western Europe produce more zonal (west-southwesterly) currents over the western Mediterranean (Fig. 3e). Figure 3b, d, f show that the synoptic conditions at $700 \mathrm{hPa}$ are well reproduced by the WRFChem simulation for each of three selected days considered here.

\subsection{Model capability to reproduce the aerosol horizontal pattern}

\subsubsection{Identification of desert dust source areas}

As described above, an important condition for the existence of a dust source is the availability of fine-grained material, which can be lifted from the ground when the surface wind speed exceeds a definite threshold. The threshold wind velocity depends on the surface roughness and grain soil size and in the literature it is found to vary from about 6 to $9 \mathrm{~m} \mathrm{~s}^{-1}$ (e.g., Chomette et al., 1999).

In order to evaluate the location of the dust sources that are directly connected with the investigated dust intrusion, in Fig. 4 we superimpose the modeled AOD at $550 \mathrm{~nm}$ (shaded contours) and the total dust flux calculated with the S01 scheme (black contours for the selected dates of 18, 20, 21, and 24 May, panels a, b, c, and d, respectively). The AOD is obtained from WRF-Chem simulations vertically integrating (from the ground to the top of domain, i.e., $20 \mathrm{~km}$ ) the aerosol extinction coefficient $\left(\alpha_{\mathrm{a}}\right)$ at $550 \mathrm{~nm}$. The same figures also show the wind field at $10 \mathrm{~m}$ (black arrows), which is directly connected with the dust emission.

The model results show that four major dust plumes were generated in different source regions of the northern Sahara on $18,20,21$, and 24 May, respectively. Then, these dust plumes were transported toward the central Mediterranean and were responsible for the consequent AOD peaks registered by the AERONET stations and for the aerosol verti- 

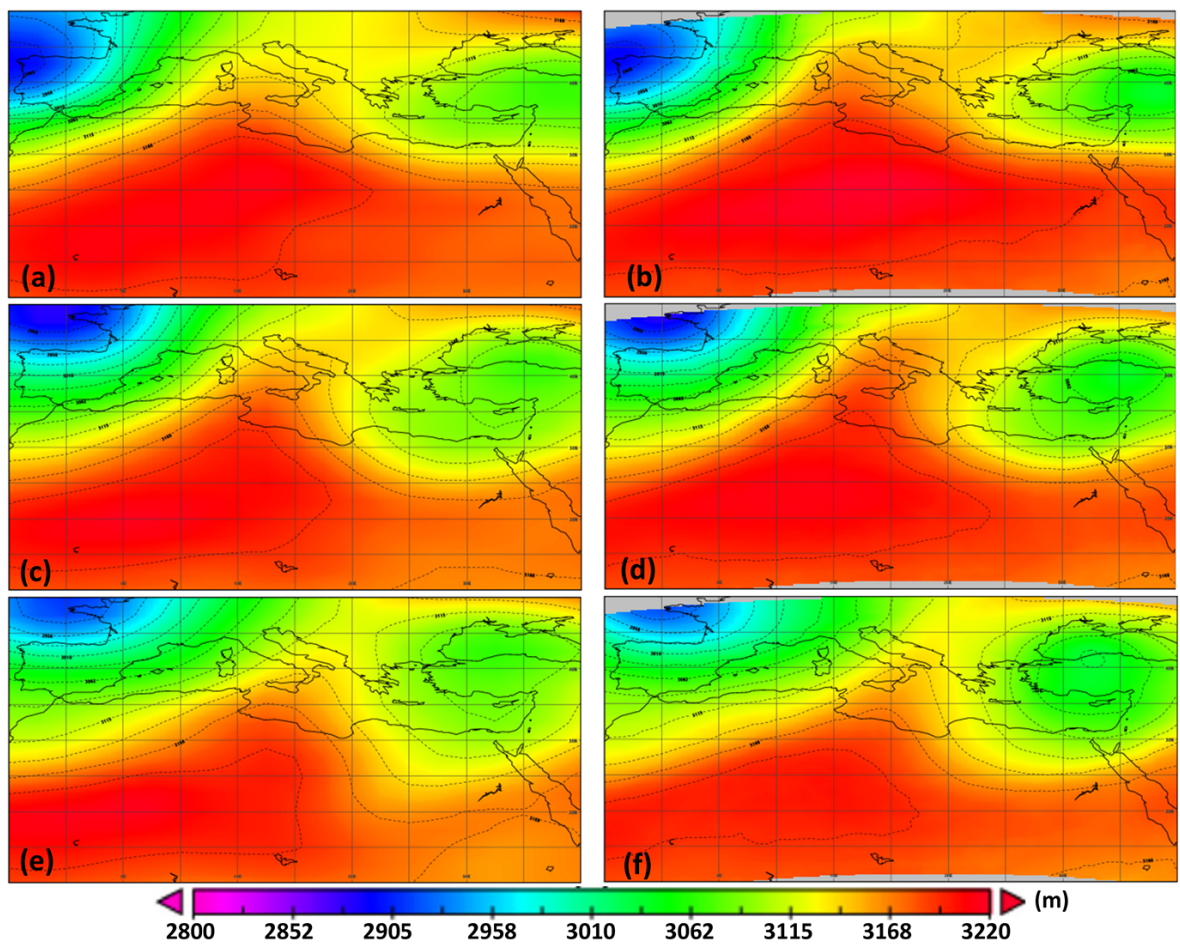

Figure 3. Geopotential height ( $1^{\circ}$ resolution) at $700 \mathrm{hPa}$ (NCEP/NCAR Reanalysis) for 21 May (a), 22 May (c), and $23 \mathrm{May}$ (e), as well as WRF-Chem geopotential height at $700 \mathrm{hPa}$ for 21 May (b), 22 May (d), and 23 May (f).

cal distribution observed by lidar in Rome (Italy) (see also Sect. 4.3).

The first dust plume (Fig. 4a) was generated by easterly surface winds of approximately $20 \mathrm{~m} \mathrm{~s}^{-1}$ speed (black arrows) in the region marked by the ellipsoid S1. The peak value of about $100 \mu \mathrm{g} \mathrm{m}^{-2} \mathrm{~s}^{-1}$ was located at about $34^{\circ} \mathrm{N}$, $8^{\circ} \mathrm{W}$, which roughly corresponds to the source area of Chott el Jerïd in Tunisia (Ginoux et al., 2012). This is a large endorheic salt lake (chott) which becomes salt flats as it dries. The emission took place between 06:00 and 16:00 UTC on 18 May. To give a reference for the following analysis, the model-based temporal evolution predicts this dust plume originated in S1 to reach the Rome area approximately at 08:00 UTC on 19 May and above $2 \mathrm{~km}$ altitude.

The second dust plume (Fig. 4b) was generated by westerly surface winds of approximately $20 \mathrm{~m} \mathrm{~s}^{-1}$ speed (black arrows) in the region marked by the ellipsoid S2. The peak value of about $100 \mu \mathrm{g} \mathrm{m}^{-2} \mathrm{~s}^{-1}$ was located at about $30^{\circ} \mathrm{N}$, $5^{\circ} \mathrm{W}$, which roughly corresponds to the source region of the Grand Erg Occidental (Ginoux et al., 2012). The emission took place between 12:00 and 18:00 UTC on 20 May. According to the model simulations, the core of this second dust plume reached Rome at about 22:00 UTC on 21 May, above $3 \mathrm{~km}$ altitude.

The third and most intense dust plume was generated on 21 May. The source region is shown in Fig. 4c and it is delimited by the ellipsoid S3, whose peak value of roughly
$120 \mu \mathrm{g} \mathrm{m}{ }^{-2} \mathrm{~s}^{-1}$ is located at $33^{\circ} \mathrm{N}, 2^{\circ} \mathrm{E}$, corresponding to the area of Chott Ech Chergui in northwestern Algeria (Ginoux et al., 2012). The surface wind speed was almost $20 \mathrm{~m} \mathrm{~s}^{-1}$. For this third plume the emission took place between 10:00 and 18:00 UTC on 21 May. This dust plume traveled very fast and arrived over Rome at about 04:00 UTC on 22 May.

A fourth, weaker dust impulse is produced on 24 May. It was generated on 24 May at 14:00 UTC on the region delimited by the ellipsoid S4 in Fig. 4d and reached Rome in the evening of the same day. Overall, this result highlights that the investigated dust event was actually characterized by multiple, superimposed dust impulses, a pattern that will be confirmed by the lidar record of desert dust profiles over Rome (Sect. 4).

All the identified source areas (S1, S2, S3, and S4) are located within a persistently active source region situated south of the Atlas Mountains and characterized by a system of ephemeral salt lakes that stay dry in summer but receives some water in winter. This system may play an important role in modulating dust emissions (Engelstaedter et al., 2006; Salvador et al., 2014). In Appendix A (Fig. A1), a view similar to that of Fig. 4 is reported except that the S11 emission scheme is used. It is evident that the two source regions evidenced in Fig. 4 by the ellipsoids S2 and S3 are not present in the latter case, thus producing a dust emission pattern not 

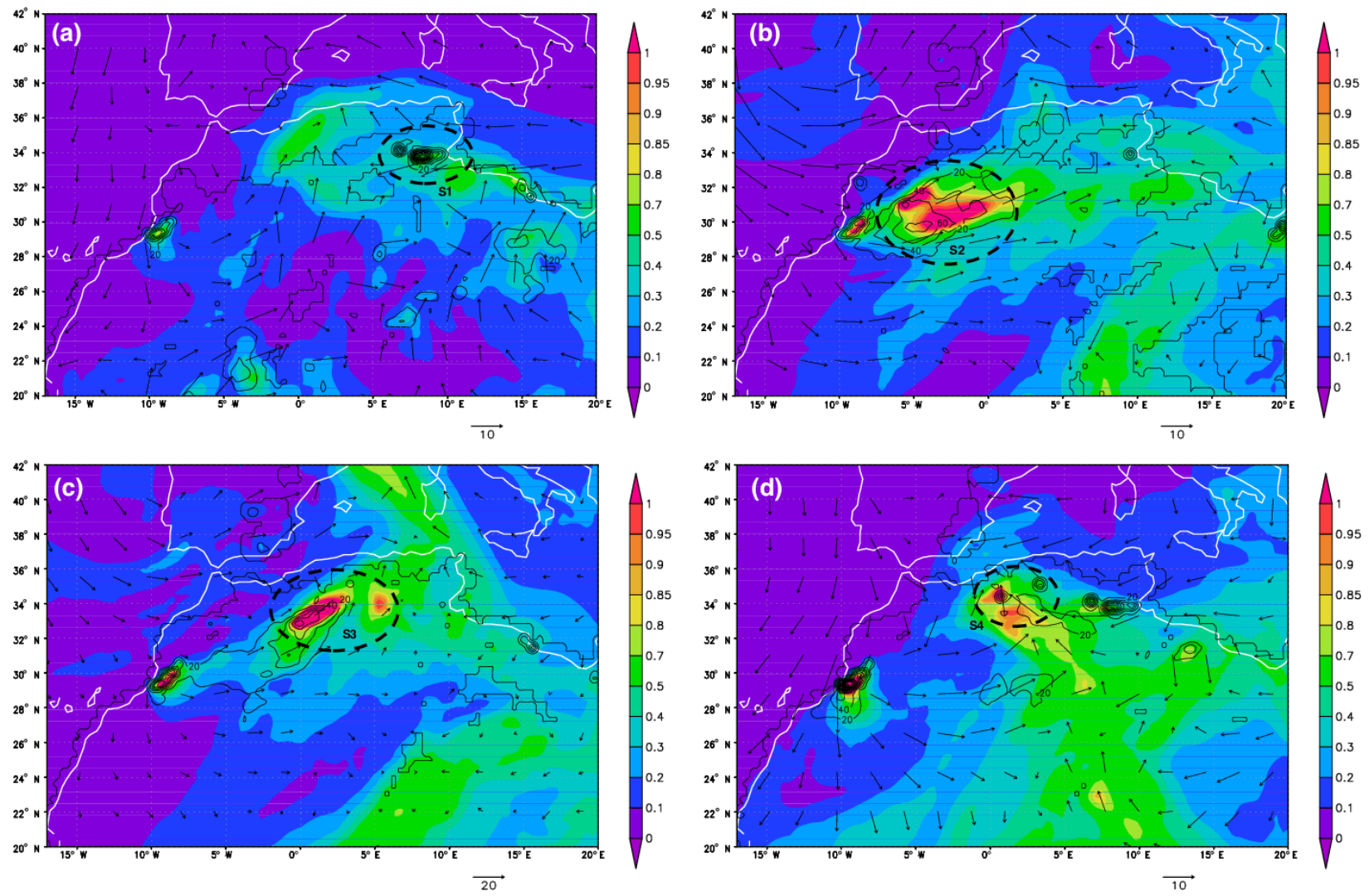

Figure 4. Model (S01) AOD at $550 \mathrm{~nm}$ (shaded contour), dust source strength (black contour) and black arrows $(u, v)$ at $1000 \mathrm{hPa}$. The dashed ovals (S1, S2, S3, S4) denote the locations of the desert regions identified as responsible for the northward dust intrusion of 18 May (a), 20 May (b), 21 May (c) and 24 May (d).

compatible with the multiple dust plumes observed by lidar (Sect. 4).

\subsubsection{Comparison of WRF-Chem and MODIS AOD over the Mediterranean}

In Fig. 5 we report the comparison between the AOD at $550 \mathrm{~nm}$ retrieved by MODIS-Terra (left column) and that predicted by WRF-Chem (S01 scheme, right column). In particular, each row of Fig. 5 corresponds to days from 20 to 23 May 2014, the left column (panels a, c, e, g) showing the MODIS-Terra AOD and the right column (panels b, d, f, h) reporting the modeled AOD.

As the Terra platform overpasses the Equator at 10:30 LT, the model results at 11:00 UTC have been considered for comparison with the satellite retrievals. The analysis of 20 May shows that the S01 and MODIS AOD have a coherent spatial pattern. In MODIS data (Fig. 5a) the highest AOD $(\approx 1.2)$ is located over the Libyan coasts and to the south of Tunisia, while the S01 AOD (Fig. 5b) roughly indicates a dust transport toward that region, with AOD peaks $(\approx 0.8)$ located mainly inland and shifted to the west compared to the observations. Both MODIS and model data do not show a marked dust transport toward the Mediterranean yet. The first intrusion in the western Mediterranean is evident the day after, when the satellite data (Fig. 5c) show a deep and intense dust frontal region $(\mathrm{AOD} \approx 1.2$ ) extending from the coasts of Algeria and Tunisia to southern France. The WRFChem AOD (Fig. 5d) shows a similar spatial distribution of the dust front, with AOD values around 0.8. The model transport toward the Mediterranean nevertheless appears slightly delayed, since high values of AOD are still present in the Sahara, different from the observations. The comparison between model and observations for 22 and 23 May is made difficult by the extensive cloud coverage in the analyzed region (gray areas in Fig. 5), which prevents the AOD retrieval from space (Fig. 5e, g). For these two days WRF-Chem shows the dust outbreak to first move toward Sardinia/Corsica and northern Italy (22 May, Fig. 5f), and then toward centralsouthern Italy and the Balkans (23 May, Fig. 5h), i.e., in the regions mostly covered by clouds (as frequent in dust-load conditions).

A similar analysis with the $\mathrm{S} 11$ emission scheme (Fig. A2 in Appendix A) shows an important under-prediction of the MODIS AOD for the whole period considered.

Overall, the picture that emerges from the (S01) simulation is that of a strong intrusion of Saharan dust in the Mediter- 

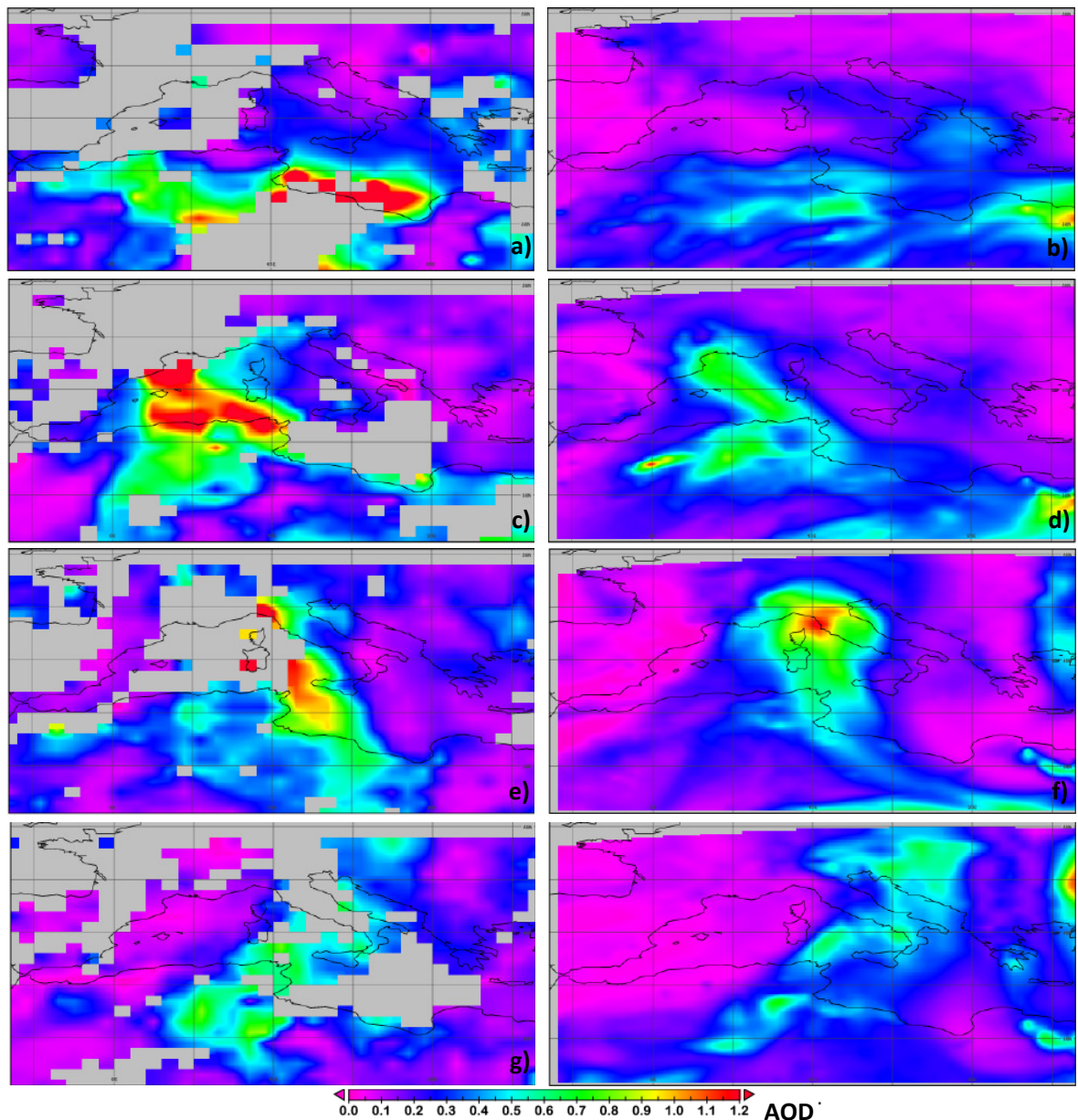

Figure 5. MODIS-Terra AOD at $550 \mathrm{~nm}$ (combined Dark Target and Deep Blue algorithms) over land and ocean at $1^{\circ}$ resolution as retrieved for (a) 20 May, (c) 21 May, (e) 22 May, and (g) 23 May, as well as model (S01) AOD distribution for (b) 20 May, (d) 21 May, (f) 22 May, and (h) 23 May, at 11:00 UTC.

ranean Basin starting from 21 May. An extensive dust front is formed and transported northward, carried out by southerly winds at $850 \mathrm{hPa}$ and southwesterly currents at $700 \mathrm{hPa}$. A second dust plume enters the Mediterranean late on 21 May and is transported toward Sardinia/Corsica and the Tyrrhenian Sea during 22 May. In the following hours the prevailing zonal flow prevents from further intrusion of Saharan dust into the basin.

\subsubsection{Comparison of WRF-Chem and ground-based AOD at specific AERONET Mediterranean sites}

To complement the comparison with the satellite observations and better follow the temporal evolution of the AOD field over the central Mediterranean, we used the AERONET measurements at the six sites shown in Fig. 1. Figure $6 \mathrm{a}-\mathrm{f}$ depict the hourly resolved AOD at $550 \mathrm{~nm}$ from the WRFChem S01 simulation (dotted line) and the corresponding AERONET measurements at the six stations (squares). The measurements show the highest AOD peaks on 21 May at
Carloforte, Sardinia (Fig. 6a, AOD =1.2), and on 22 May at Ersa, Corsica (Fig. 6c, AOD =1.2), with high values also measured in central (Fig. 6b) and northern (Fig. 6d) Italy (Rome up to $\mathrm{AOD}=0.8$ and Modena up to $\mathrm{AOD}=0.9$ ). Note that, due to the extensive cloud coverage over the Tyrrhenian Sea, Carloforte has no data on 22 May and Rome on 23 May. The other two stations, Calern in Southern France (Fig. 6e) and Ispra in northwestern Italy (Fig. 6f), are shown to be less impacted by the dust plume (AOD $<0.4$ all over the period investigated). For the sites of Rome and Modena, WRFChem reproduces the AERONET measurements quite well, showing similar AOD time evolutions. At the Carloforte station, the simulation shows three AOD peaks on 19,21, and 22 May, while measurements only confirm the 21 May one, the other two dates being affected by clouds. At the Ersa station, the simulation shows a main peak on 22 May, in agreement with the observations; in general, the measured AOD is well reproduced for the whole period. The corresponding results for the S11 scheme simulation are reported in Fig. A3 

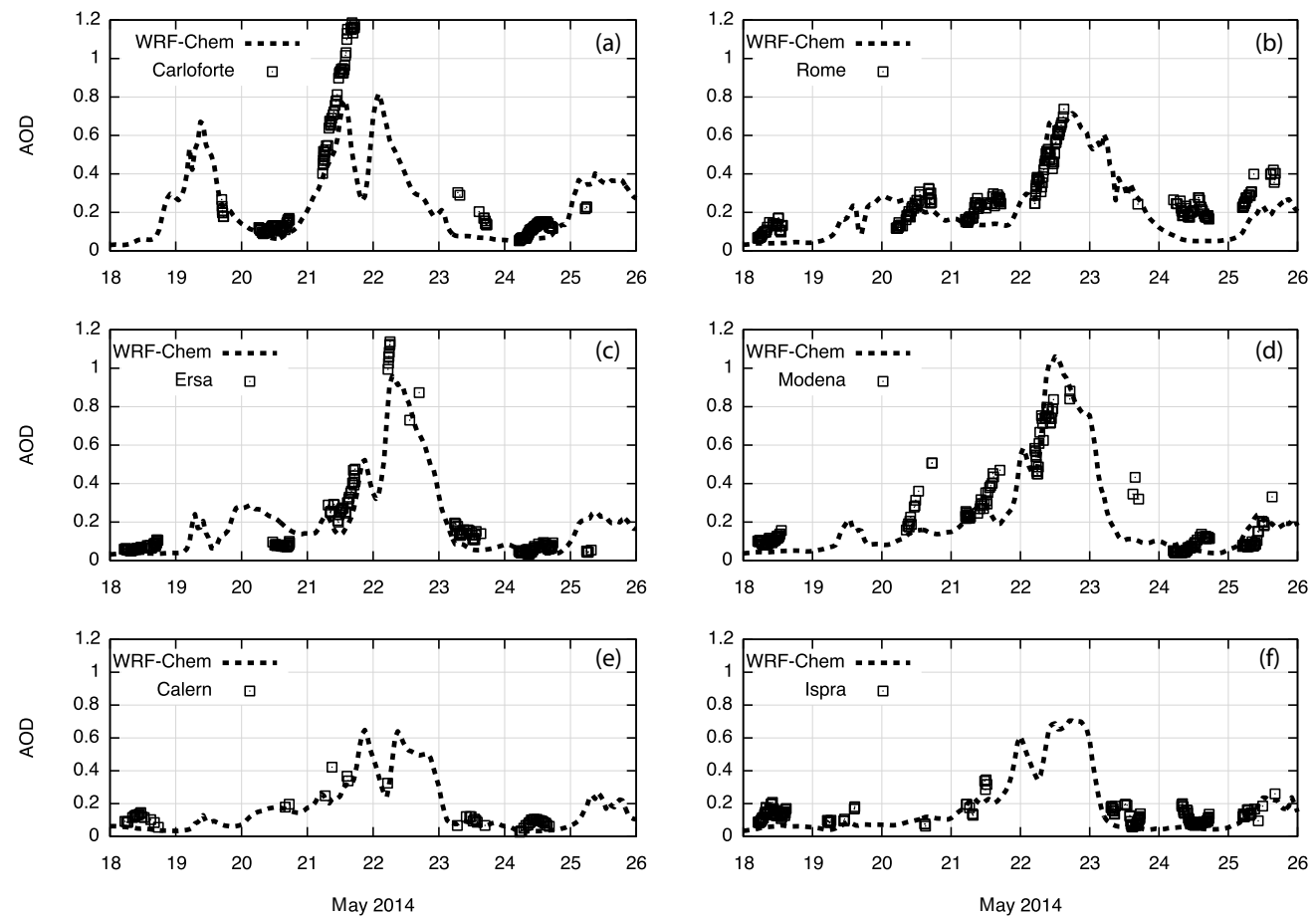

Figure 6. Hourly resolved columnar AOD at $550 \mathrm{~nm}$ as obtained from the WRF-Chem (S01) simulation (dotted lines) and from AERONET measurements (squares) at the six stations of (a) Carloforte, (b) Rome, (c) Ersa, (d) Modena, (e) Calern, and (f) Ispra (see also Fig. 1).

Table 3. Mean AOD predicted by the two model schemes, as well as their bias and temporal correlation with respect to corresponding AERONET measurements.

\begin{tabular}{lccc}
\hline Scheme & Mean AOD & Bias & Corr. coeff., $R$ \\
\hline S01 & 0.15 & -0.06 & 0.85 \\
S11 & 0.09 & -0.12 & 0.71 \\
\hline
\end{tabular}

in Appendix A. As expected from the previous comparison to MODIS AOD data, the results confirm the relevant S11 AOD under-prediction at the six AERONET sites. To quantify the model vs. AERONET agreement, the mean bias and the temporal correlation coefficient for the six AERONET stations are reported in Table 3 (for both S01 and S11 cases). Overall, the average S01 AOD for the whole period for the six stations is 0.15 , corresponding to a bias of -0.06 and an $85 \%$ of temporal correlation coefficient with respect to AOD measurements. For comparison, the $\mathrm{S} 11$ prediction produces a larger AOD negative bias $(-0.12)$ and a lower correlation $(71 \%)$.

This perspective shows that the maximum of a (first) dust plume reached southern Sardinia on 21 May, while in the easternmost sites (Ersa, Ispra, Rome) the maximum AOD is detected on 22 May. This result confirms and integrates the analysis of satellite data, while the lidar view in Rome (next section) will further show that the latter maximum comes from the superposition of a second plume traveling above the first one.

\subsection{Model capability to reproduce the desert dust plume vertical patterns}

The vertical evolution of the desert dust plume over Rome is revealed by the lidar and ceilometer measurements (see Sect. 2). Figure 7 shows the altitude (0-6 km) vs. time (h24) cross section of the aerosol field as detected by both the CHM15k ceilometer (Fig. 7a) and the ATLAS lidar systems (Fig. 7b), and forecasted by the model (Fig. 7c) for the period 19-25 May 2014. In particular, Fig. 7a shows the logarithm of the range-corrected signal (RCS) of the CHM15k system, which, to a first approximation, is proportional to the atmospheric aerosol load. Figure $7 \mathrm{~b}$ shows the particle depolarization ratio, derived from the two ATLAS receiving channels. This parameter is a "marker" for the presence of non-spherical particles and is therefore particularly suitable for following the desert dust plume evolution in space (over the vertical scale) and time.

The ceilometer measurements (Fig. 7a) also allow for the temporal evolution of the (aerosol-tracked) planetary boundary layer (PBL) to be followed in each day of the period considered. This can be identified by the green, bell-shaped areas reaching a maximum altitude of about $2 \mathrm{~km}$ (particularly evident on 20, 21, 22 May). On 19 and 23 May, the boundary 
(a)

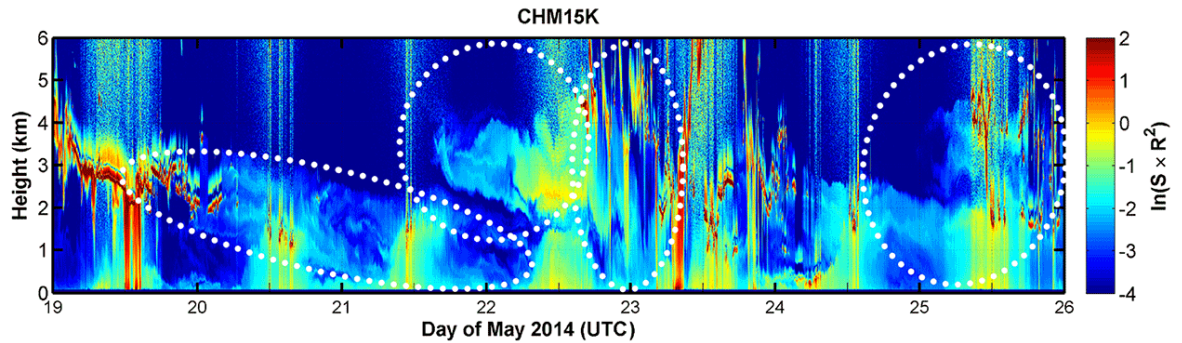

(b)

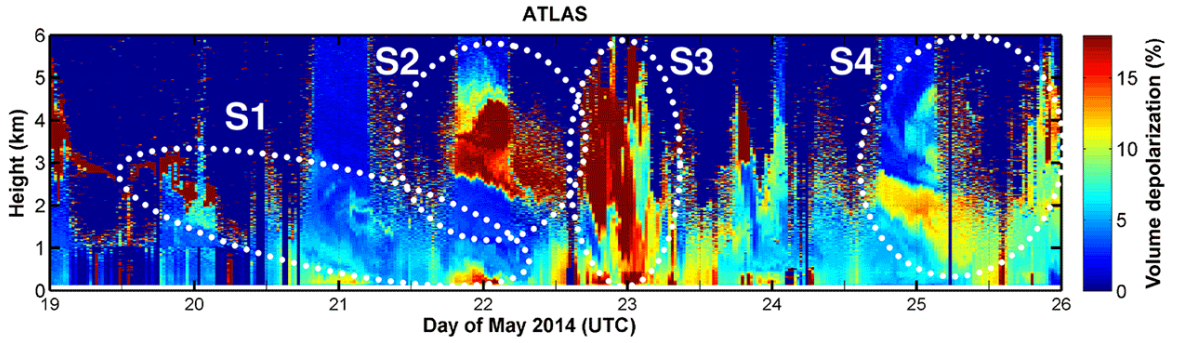

(c)

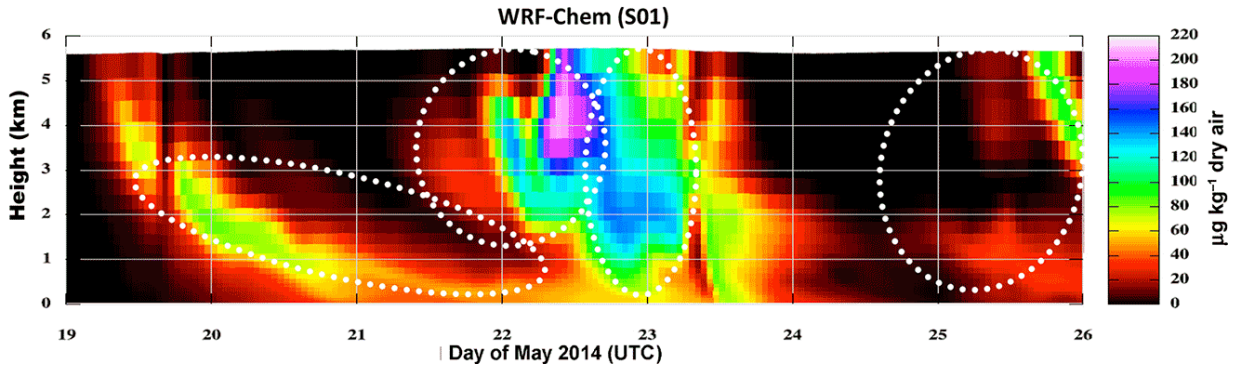

Figure 7. Continuous (h24) temporal evolution (19-25 May, $x$ axis) of the vertically resolved (0-6 km, $y$ axis) aerosol field over Rome as observed/modeled by (a) the CHM15K ceilometer (aerosol-produced range corrected signal, RCS), (b) the ATLAS lidar (aerosol-induced volume depolarization, $D, \%$ ), and (c) the WRF-Chem S01 scheme (total dust mass, $\mu \mathrm{g} \mathrm{kg}_{\text {dry air }}^{-1}$ ).

layer signal is somehow "perturbed" by the presence of rain and clouds (red coloring in Fig. 7a).

Above the PBL, elevated aerosol layers are clearly visible in the ceilometer trace. These have been highlighted by dotted, white oval shapes in Fig. 7a. Although the (elastic) ceilometer signal of Fig. 7a does not allow for discrimination of the aerosol type, these elevated layers over Rome are typically associated with Saharan dust (e.g., Gobbi et al., 2004, 2013). To prove these layers are actually composed of mineral (non-spherical) particles, Fig. 7b shows them to produce a depolarization signal typical of long-range transported desert dust (volume depolarization $>8 \%$ ). To facilitate the spatiotemporal comparison between the two lidars measurements and the model outcome, the same dust-identification oval shapes have been reported in each panel of Fig. 7.

Overall, the lidar measurements in the period 19-25 May reveal the desert dust advection to occur in several, superimposed desert dust plumes, thus confirming the "pulsed" nature of this event simulated by the S01 configuration (Fig. 7c, see also Sect. 4.2.1). In most of the cases both measurements and simulation show the desert dust to travel above the PBL and then to descend and mix with the local aerosols within it. In particular, four main different desert dust plumes, identified to originate over different source regions in Sect. 4.2.1, can be detected in the lidar/ceilometer records (oval shapes in Fig. 7a, b). A first plume arrives over Rome on 19 May (although the presence of clouds hinders establishing the exact time of its arrival over the city); thereafter it progressively descends and is firstly detected at the ground on 20 May. This is compatible with the modeled plume originated in the source area S1 in Fig. 4. A second plume, compatible with the one originated by the model in S2 (Fig. 4), reaches the atmosphere near Rome above $2 \mathrm{~km}$ height in the evening of 21 May and then descends towards the ground. This plume superimposes itself on the previous one, and on a third major plume arriving in the afternoon of 22 May and extending from the ground up to $6 \mathrm{~km}$ (this is the major plume the model identifies to originate in the source region S3, Fig. 4). The mixing of the three plumes is observed down to the ground until at least 24 May. As predicted by the model, a fourth and weaker pulse arrives aloft in the night between 24 and 25 May and superimposes itself on the previous ones until the end of the analyzed period. 

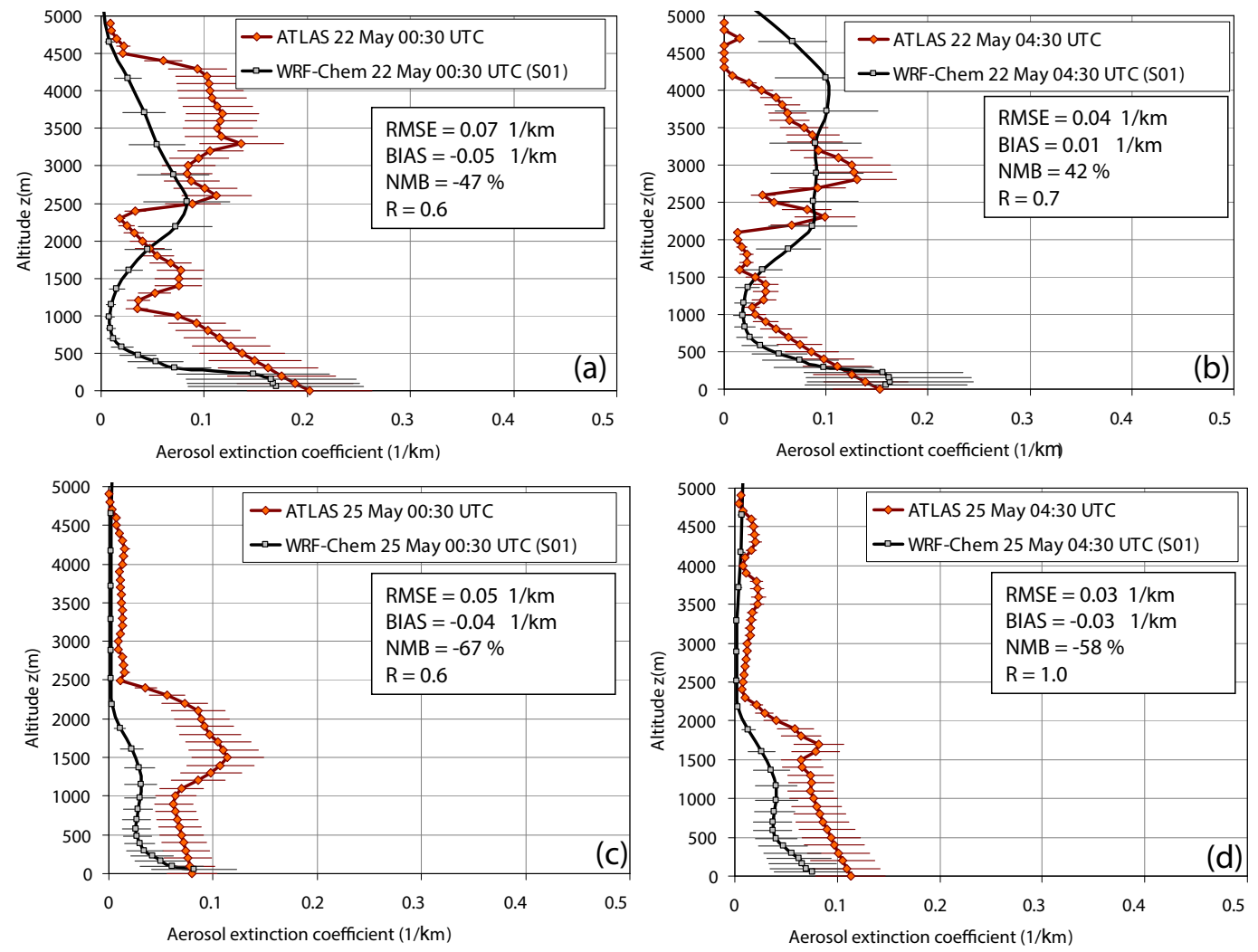

Figure 8. Vertical profiles $\left(0-5 \mathrm{~km}, y\right.$ axis) of the $1 \mathrm{~h}$ mean aerosol extinction coefficient $\left(\mathrm{km}^{-1}\right)$ in Rome as retrieved by the ATLAS lidar data (at $532 \mathrm{~nm}$, red line, orange diamonds) and simulated by the WRF-Chem (S01) model (at $550 \mathrm{~nm}$, black line, gray squares). Error bars associated with the lidar data represent an expected $30 \%$ error in the lidar retrieval (see text), while a 50\% error bar has been associated with the model values. Top (a, b) and bottom (c, d) panels refer to 22 and 25 May, respectively. Left (a, c) and right (b, d) column panels refer to profiles at 00:30 and 04:30 UTC, respectively.

Although qualitatively, lidar measurements at high vertical and temporal resolution allow to evaluate the model capability to reproduce the desert dust plume vertical patterns and timing. In particular, the comparison of Fig. $7 \mathrm{a}$ and $\mathrm{b}$ with Fig. 7c shows the model is able to reproduce well the "pulsed" pattern of this desert dust advection, reproducing both its timing and vertical extent quite well. Some differences are found with the timing and vertical location of the fourth plume, which the measurements indicate to arrive at about $2 \mathrm{~km}$ around noon of 24 May and the model predicts at lower altitudes and with some hours of delay. Nevertheless, the model is still capable of reproducing the second peak of this fourth plume observed by the lidar systems aloft (above $3 \mathrm{~km})$.

A more quantitative validation of the vertically resolved model output is provided in Fig. 8, in which the ATLAS lidar range-corrected signal (RCS) is inverted to derive the aerosol extinction coefficient (see Sect. 3.3.1). For this purpose, nighttime/early-morning profiles have been selected to improve the signal-to-noise ratio in the measurements and thus facilitate the lidar signal inversion. Figure 8 shows that the model mostly reproduces the general vertical pattern of the desert dust plume, with a double-layer structure clearly evident on 22 May (Fig. 8a, b). The elevated layer is likely uniquely composed of desert dust particles (as revealed by the lidar depolarization trace in Fig. 7), while in the PBL aerosol layer, desert dust is mixed with (spherical) particles of local origin. Overall, for this date, which corresponds to the maximum desert dust load over Rome (see also Fig. 6b), the model reproduces the associated aerosol extinction along the vertical profile (Fig. 8a, b) quite well, with an estimated normalized mean bias (NMB) with respect to the lidar ranging from $-50 \%$ of the midnight profile (Fig. 8a) to $+50 \%$ of the early morning one (Fig. 8b).

As expected, the model is, however, unable to reproduce the "fine" structure of the desert dust plume (minor thin layers within the main ones) revealed by the high vertical resolution of the lidar trace. This translates into a moderate correlation $(R \sim 0.6,0.7)$ between the modeled and the observed aerosol extinction profiles. This vertically resolved perspective also provides further insight in the good matching between the model and the measured AOD over Rome on 22 May (Fig. 6b), showing that it partly derives from "compensation effects" between a modeled underestimated 

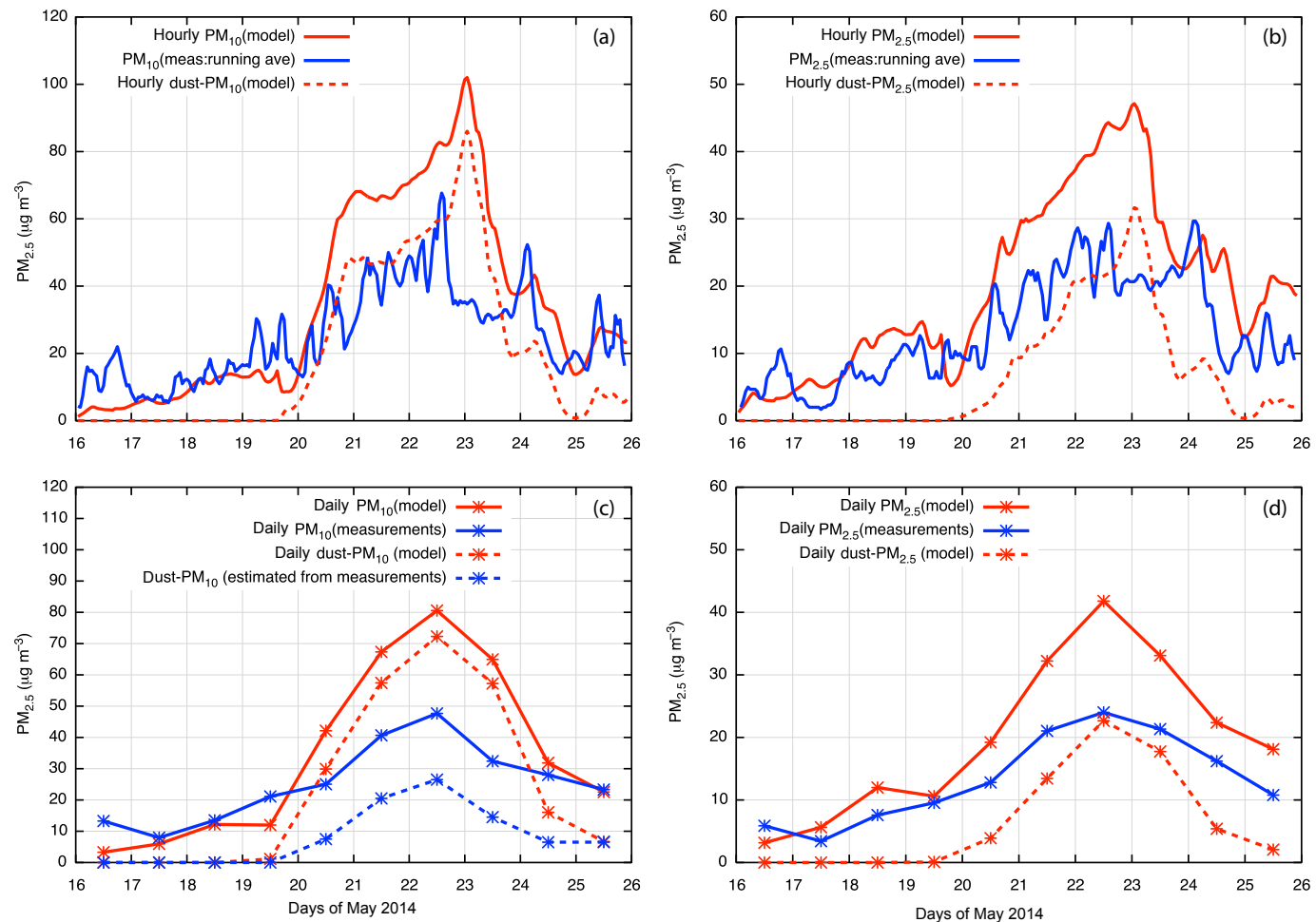

Figure 9. Temporal evolution of surface level $\mathrm{PM}_{2.5}$ and $\mathrm{PM}_{10}$ values and relevant desert dust contribution at Rome (Castel di Guido site) during the investigated period: (a) hourly resolved evolution of S01 modeled $\mathrm{PM}_{10}$ (red continuous line), S01 modeled desert dust PM 10 (red dashed line), and $\mathrm{PM}_{10}$ measurements ( $3 \mathrm{~h}$ running average, blue continuous line); (b) as in (a) but for $\mathrm{PM}_{2.5}$; (c) as in (a) but for daily-averaged data - in addition, daily desert dust $\mathrm{PM}_{10}$ values obtained from measurements have been reported (dashed blue line) (see text for details); and (d) as in (b) but for daily-averaged data.

aerosol extinction in the lowermost levels and a model overestimation aloft. Similarly, the vertically resolved comparison for 25 May (Fig. 8c, d) allows us to better understand why the model underestimates the AOD (Fig. 6b) in such lower desert dust loads. In fact, although the model is still able to reproduce the shape of the aerosol profile (moderate to excellent correlation in Fig. 8c, d), in this case it clearly under-predicts the aerosol extinction (NMB of about $-60 \%$ ). This view, and particularly the steeper decrease of the aerosol extinction with height in the lowermost levels, also points to some underestimation of the PBL height by the model. The same model vs. lidar quantitative comparison employing the S11 simulation is reported in Fig. A4, once again highlighting the worse performances of this configuration with respect to the S01 one. In fact, in this case a very low aerosol extinction coefficients is associated with the desert dust plume, and the vertical structure observed by lidar is completely lost in this simulation.

\section{Comparison to ground-level PM values}

A further quantitative evaluation of the model ability to reproduce the observed aerosol/dust load is given in Fig. 9, where the aerosol mass concentration predictions at the par- ticular vertical level coincident with the ground are compared to in situ-measured $\mathrm{PM}_{10}$ and $\mathrm{PM}_{2.5}$ data, these being the metrics regulated by the European Air Quality Directive 2008/50/EC (EC, 2008). In particular, in Fig. 9 modelsimulated (red curve) and in situ-measured (blue curves) $\mathrm{PM}_{10}$ (Fig. 9a, c) and $\mathrm{PM}_{2.5}$ (Fig. 9b, d) are shown at both hourly (top panels) and daily (bottom panels) resolution. The contribution of desert dust to the total $\mathrm{PM}_{10}$ and $\mathrm{PM}_{2.5}$ as derived by the model is also shown in the plots (dust $\mathrm{PM}_{10}$ and dust $\mathrm{PM}_{2.5}$, red dashed lines in each panel). For comparison, the contribution of desert dust as estimated from the $\mathrm{PM}_{10}$ measurements as described in Barnaba et al. (2017) is provided in Fig. 9c (dashed blue lines, blue star symbols).

Overall, the results show a marked over-prediction of both $\mathrm{PM}_{2.5}$ and $\mathrm{PM}_{10}$ during the event (20-24 May), with model and measured PM fields better matching in dust-free or lowdust conditions (i.e., before 20 May). The hourly-resolved temporal evolution of the $\mathrm{PM}_{10}$ and $\mathrm{PM}_{2.5}$ fields also reveals some $12 \mathrm{~h}$ time shift of the PM maximum values, these being observed around midday of 22 May and predicted in the night between 22 and 23 May by the model. This time shift is, however, somehow hidden/modulated in the daily-average comparison, the latter showing a better synchronization between the two, with coincident maxima on 22 May. The 
marked model overestimation is, however, obviously still evident in the daily-resolved plots and is clearly related to a model overestimation of the desert dust component within the (total aerosol) $\mathrm{PM}_{10}$ and $\mathrm{PM}_{2.5}$ metrics. In fact, the model predicts desert dust to contribute up to $90 \%$ of the total $\mathrm{PM}_{10}$ In quantitative terms, the comparison to the observed desert dust mass concentration reveals that the model overestimates the daily-average desert dust $\mathrm{PM}_{10}$ by a factor of $2-3$, as the observed desert dust contributes to less than $50 \%$ of the (total aerosol) daily $\mathrm{PM}_{10}$.

As the comparison of the aerosol extinction profiles does not show a similar model overestimation in the lowermost levels (e.g., Fig. 8), this result points to a probable misrepresentation of the desert dust size distribution within the model, with an over-predicted role of large particles (impacting total aerosol mass more than aerosol extinction coefficient at $550 \mathrm{~nm}$ ). Furthermore, we speculate that an important factor in determining the poor model performance in predicting the PM fields could be related to an inadequate representation of the desert dust wet removal. In fact, the wet removal by convection-driven (parameterized) precipitation is neglected in the simulation (Sect. 2.1.2), while it contributes to about $40-50 \%$ of the total rainfall simulated by the model (see Sect. 2.1.2). The event under investigation was associated with precipitation both during the northward advection of desert dust (particularly over the Mediterranean Sea between Sardinia and central Italy, not shown) and during its transit over the Rome observational site (rain detected on 19 and 23 May, as visible from Fig. 6a). This aspect would certainly merit further investigation by including a new dust wet deposition scheme in the model setup (for example the one recently developed by Tsarpalis et al. (2017) which explicitly considers the rate of dust scavenged by precipitation inside and below the cloud, based on the parameterization proposed by Seinfeld and Pandis, 1998). This further analysis is, however, beyond the purpose of the current study.

\section{Conclusions}

This study evaluates the performances of a physics-based desert dust emission scheme within the WRF-Chem model. In particular, we used the physics-based dust emissions scheme proposed by Shao (2001) (here S01) to simulate an important dust outbreak occurred over the central Mediterranean regions in the period 19-24 May 2014, and we compared the simulations to a large set of aerosol/desert dust observations. To highlight the advantages of using a detailed physically based scheme, the performances of the S01 configuration were also compared with the outcome of its simplified (minimal) version (Shao et al., 2011, here S11), in which the emission is independent of the sand particle size. In all the comparisons S01 outperformed the S11 scheme as described in the text and documented in Appendix A.
In the case study considered here, the intrusion of mineral dust in the Mediterranean was associated with a synopticscale omega-like pressure configuration with a cyclogenesis in the Atlantic coasts of Spain. The cyclone was responsible for strong westerly Atlantic winds affecting the northern Sahara, while the northward transport was made possible by southwesterly currents on the west side of the ridge associated with the omega-like pattern. In general, the synoptic conditions for the geopotential height at $700 \mathrm{hPa}$ were well reproduced by WRF-Chem. This allowed us to simulate with good confidence the path of the dust during the northward intrusion.

A first comparison between the modeled aerosol optical depth (AOD) field and source emission functions allowed us to identify four different source regions of desert dust for the investigated northward intrusion. In particular, we recognized a persistently active source region located south of the Atlas Mountains and between Algeria and Tunisia, confirming some recent findings from Ginoux et al. (2012). This region is in fact characterized by a system of ephemeral salt lakes that stay dry in summer but receive some water in winter, playing an important role in modulating the dust emissions.

A multi-platform observational dataset (including satellite, AERONET, lidar, and in situ PM data) was used to test the ability of the model to reproduce the spatiotemporal pattern of the dust intrusion, which was found to be composed of several superimposed, time-shifted dust pulses.

On the horizontal scale, the comparison between the modeled AOD field with the corresponding satellite retrievals (MODIS-Terra) showed the WRF-Chem simulation to satisfactorily resolve the arrival, the temporal evolution, and the extent of the plumes over the central Mediterranean. Results also showed a good agreement between the modeled $\mathrm{AOD}$ and the one measured from the ground at six selected AERONET sites in the Mediterranean region (correlation coefficient, $R=0.85$ ). The combined analysis of AERONET data and simulations showed that the first dust intrusion occurred on 21 May reaching southern Sardinia, the second and most intense dust plume occurred on 22 May, penetrating up to northern Corsica and central Italy. This result confirms and complements the analysis from the polar satellite data (Terra), which is necessarily limited in time.

The characterization of the aerosol field over the vertical scale was made here by employing continuous (h24) lidar/ceilometer measurements performed in a single observational point that lies just in the middle of the area investigated (Rome, Italy) and was therefore expected to be particularly suitable to evaluate the model capability to reproduce the dust plume vertical extent and its transport timing. Overall, the lidar measurements in the period 19-25 May clearly highlighted the "pulsed" nature of the event examined. In most of the cases the desert dust is shown to arrive above the PBL and then to descend and mix with the local aerosols within it. The comparison with lidar measure- 
ments also highlighted that the good matching between the model and measured AOD comes from a rather good reproduction of the aerosol extinction coefficient along the profile (normalized mean bias, NMB, of about $50 \%$ ), with the best performances in terms of aerosol optical properties obtained during the maximum of the dust event (minimum bias between the modeled and the measured aerosol extinction coefficients). During the weaker desert dust conditions registered at the end of the event, the model is shown to reproduce well the shape of the observed vertical extinction profile (correlation coefficient $R$ up to 1), although with a marked underestimation (NMB of about $-60 \%$ ). When the model-measurement comparison was done at ground level in terms of aerosol mass $\left(\mathrm{PM}_{2.5}\right.$ and $\mathrm{PM}_{10}$ data are used for this purpose), a tendency to overestimate the desert dust aerosol mass was conversely revealed. Such an overestimation reaches $70 \%$ for $\mathrm{PM}_{10}$ and $\mathrm{PM}_{2.5}$ during the dust peak, reduced to $10-60 \%$ in weak-dust or no-dust conditions (before 20 May and after 23 May). For $\mathrm{PM}_{10}$ it was possible to show that the total mass overestimation is driven by an overestimated dust contribution of the order of $140 \%$. This result points to a possible over-prediction of the number of large dust particles by the model (affecting dust mass more than optical properties). Additionally, we speculate that at least part of the model $\mathrm{PM}_{2.5}$ and $\mathrm{PM}_{10}$ overestimation might be related to the simplified wet removal scheme adopted, which only considers non-convective (resolved) precipitation as active in the desert dust removal processes. In fact, particularly in the central phase of the dust event recorded in Rome, convective precipitation was registered over the central Mediterranean, between Sardinian and the Italian Tyrrhenian coast. This aspect deserves further investigation and will be addressed in a future work together with the tuning of the several model internal parameters that characterize these kinds of size-resolved dust fluxes.

\section{Data availability}

WRF-Chem simulation data are available upon request to Umberto Rizza (u.rizza@isac.cnr.it). Lidar, ceilometer and PM data are available upon request to Gian Paolo Gobbi (g.gobbi@isac.cnr.it). Ceilometer images can be found at http://www.alice-net.eu. AERONET data are available at http://aeronet.gsfc.nasa.gov/. 
Appendix A
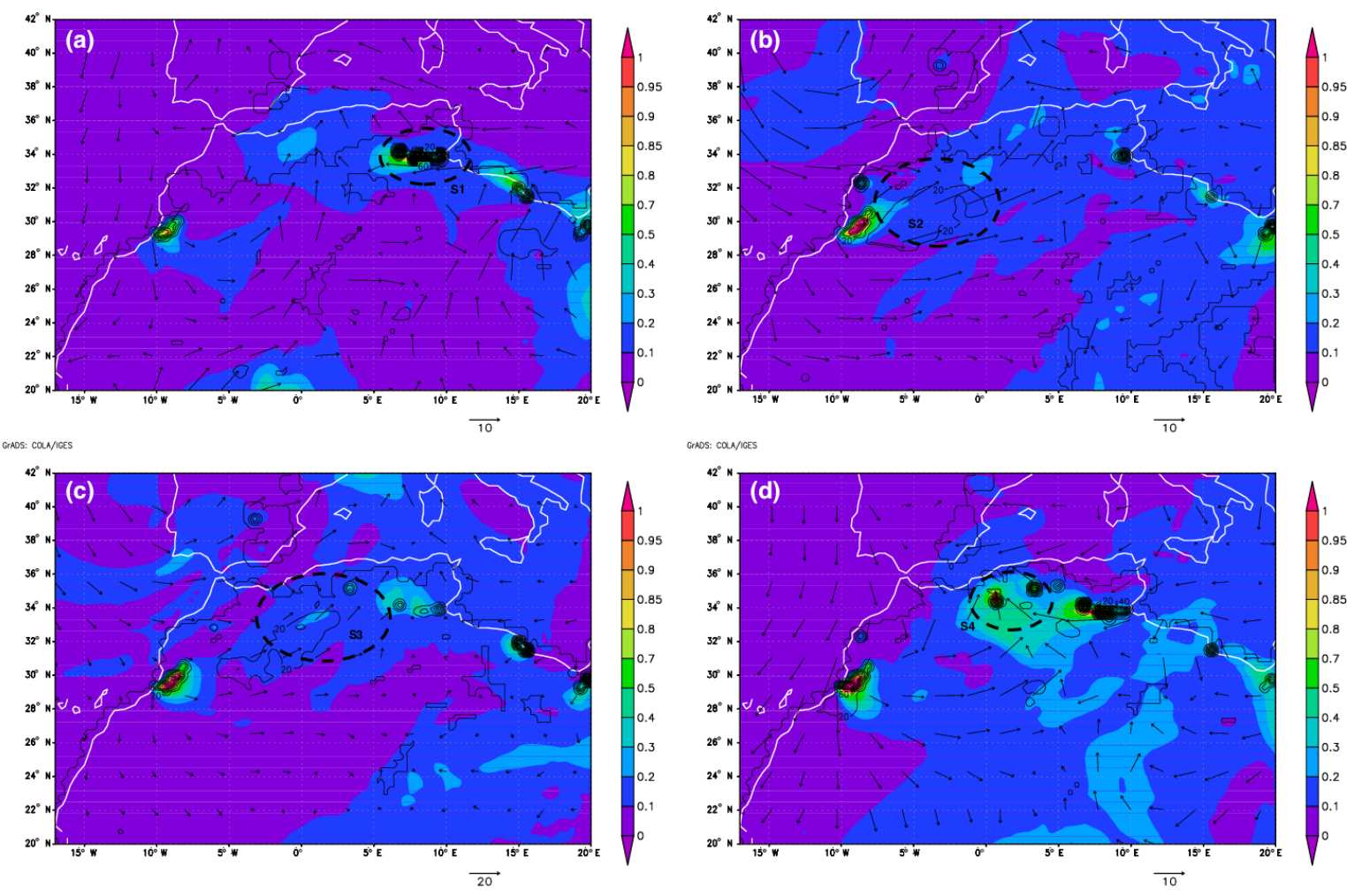

Figure A1. As in Fig. 4 except that the S11 rather than the S01 configuration is used.

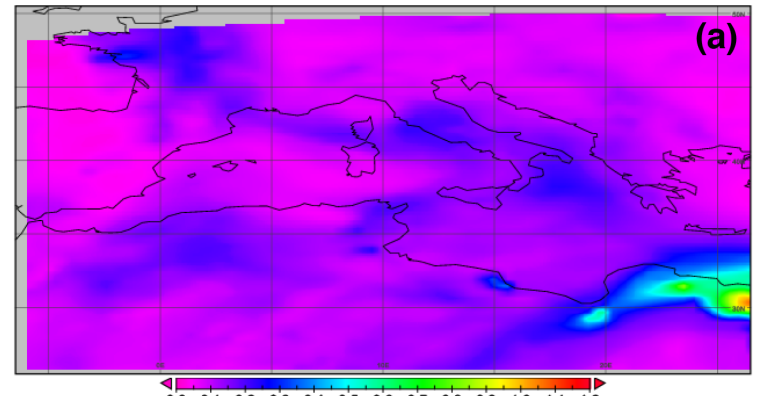

$\begin{array}{llllllllllllllll}4 & 0.0 & 0.1 & 0.2 & 0.3 & 0.4 & 0.5 & 0.6 & 0.7 & 0.8 & 0.9 & 1.0 & 1.1 & 1.2\end{array}$

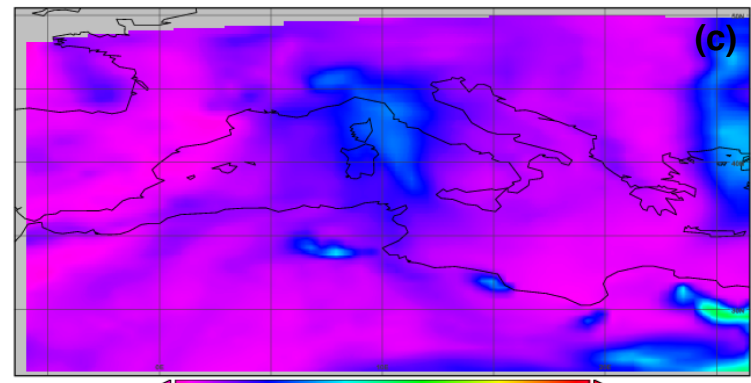

$\begin{array}{lllllllllllllll}4 & 0.0 & 0.1 & 0.2 & 0.3 & 0.4 & 0.5 & 0.6 & 0.7 & 0.8 & 1 & 0.9 & 1.0 & 1.1 & 1.2\end{array}$

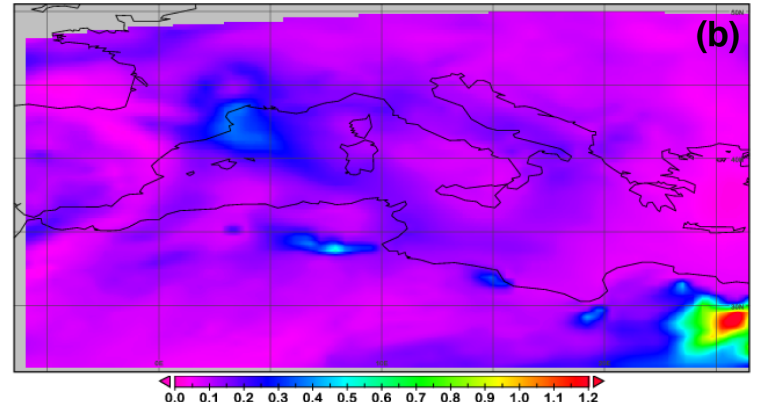

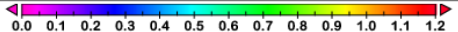

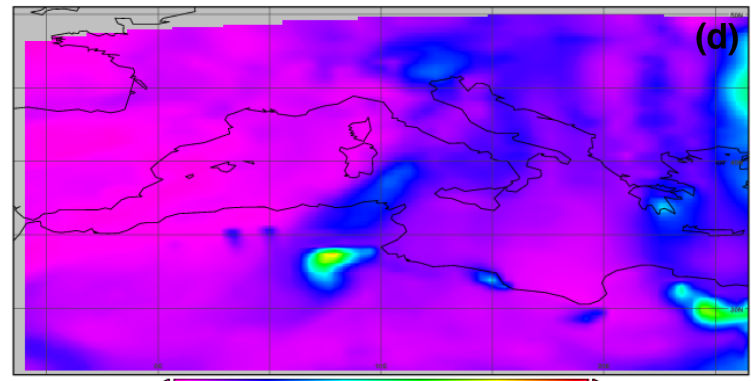

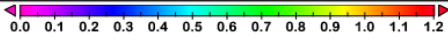

Figure A2. As in Fig. 5 (right panel) except that the S11 rather than the S01 configuration is used. 

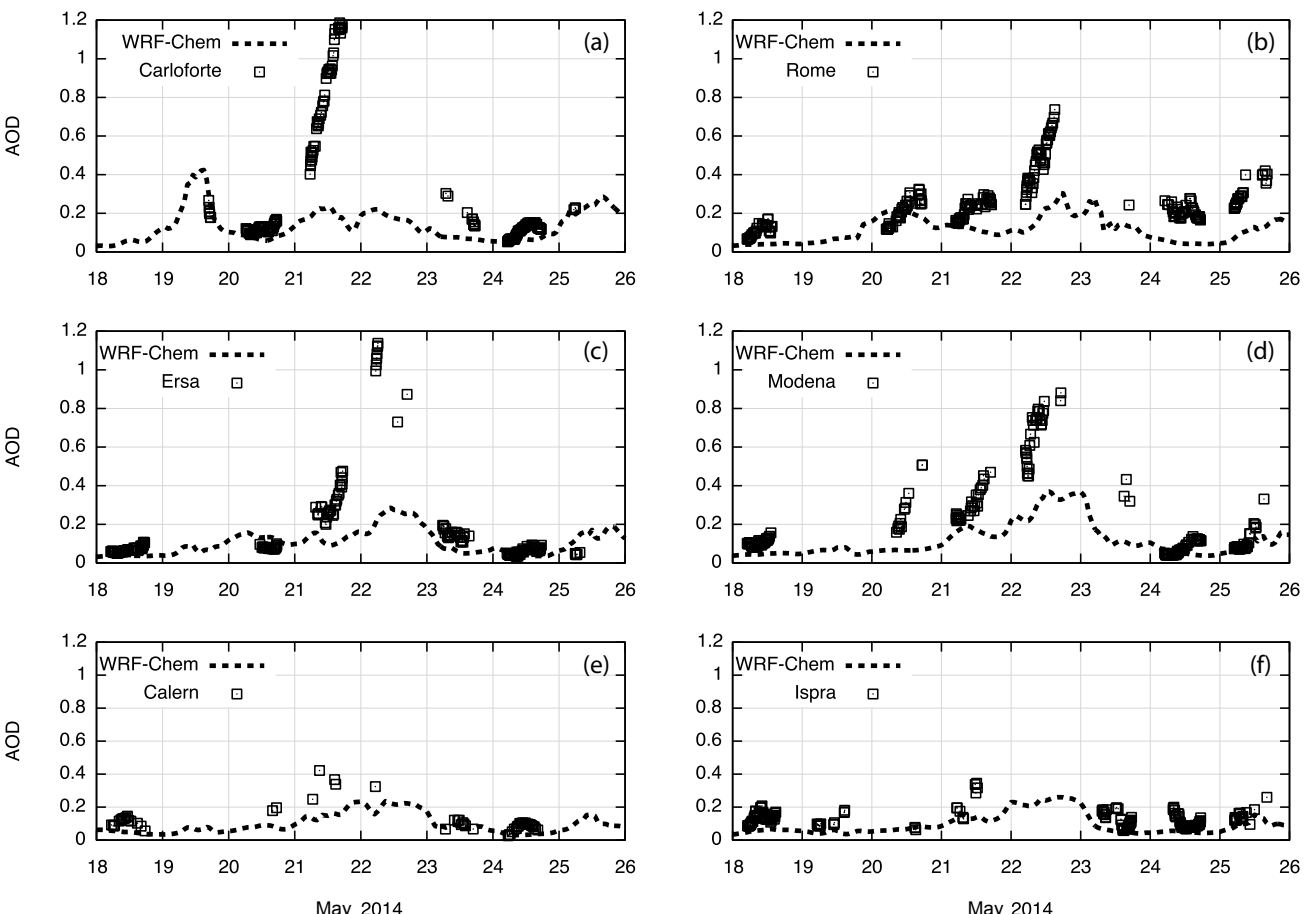

Figure A3. As in Fig. 6 (right panel) except that the S11 rather than the S01 configuration is used.
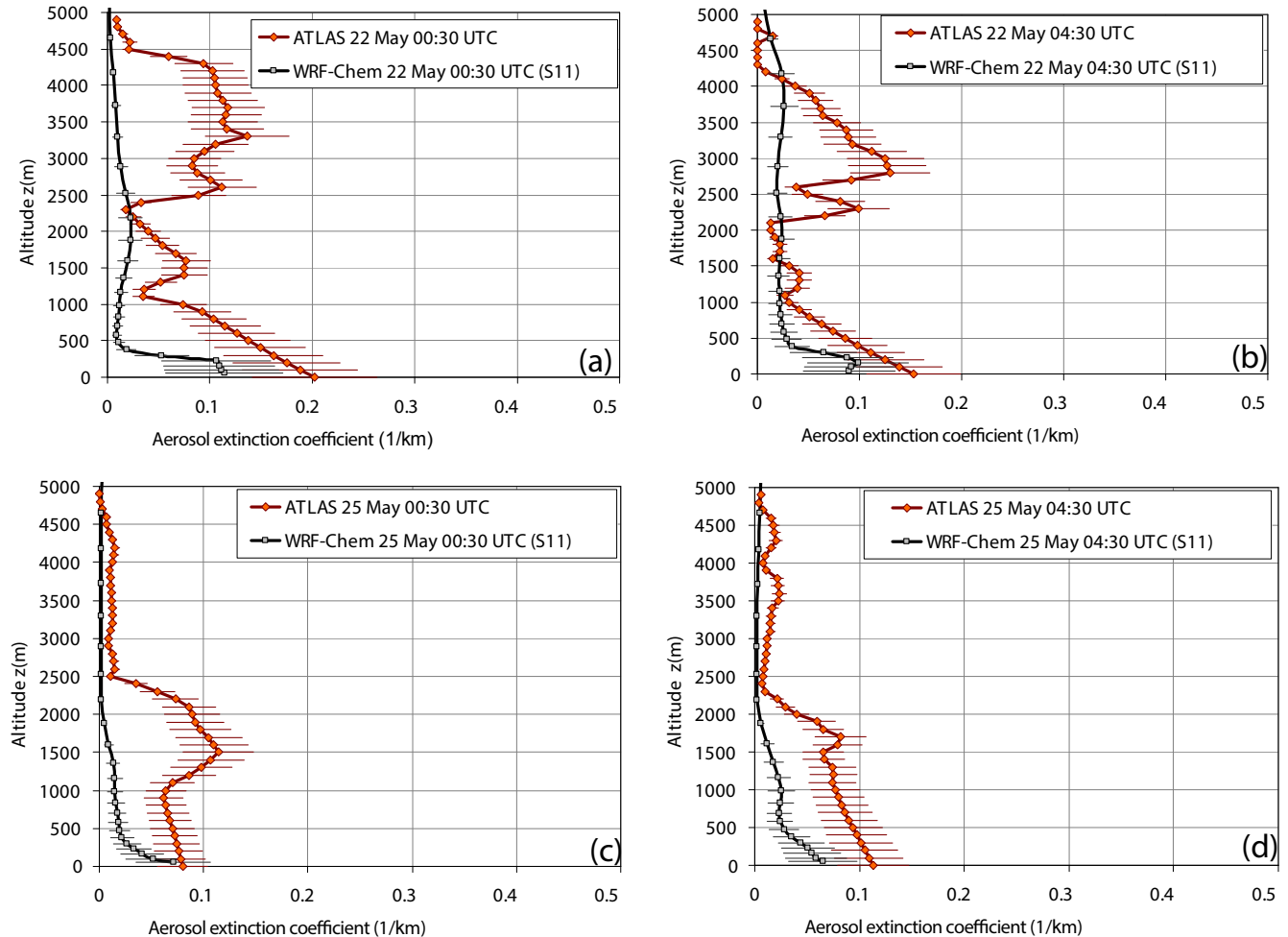

Figure A4. As in Fig. 8 except that the S11 rather than the S01 configuration is used. 
Acknowledgements. Analyses and visualizations used in this paper were produced with the Giovanni online data system, developed and maintained by the NASA GES DISC (http://giovanni.gsfc.nasa.gov/). We also acknowledge the MODIS mission scientists and associated NASA personnel for the production of the data used in this research effort. NCEP Reanalysis data were provided by the NOAA/OAR/ESRL PSD, Boulder, Colorado, USA, from their Web site at http://www.esrl.noaa.gov/psd/. We thank the principal investigators and their staff for establishing and maintaining the AERONET sites, the data from which have been used in this study. The aerosol and desert dust observations in Rome (Italy) employed in this work were supported by the EC-LIFE+DIAPASON project (LIFE+10 ENV/IT/391).

Edited by: J. Huang

Reviewed by: two anonymous referees

\section{References}

Alpert, P. and Ziv, B.: The Sharav cyclone: observations and some theoretical considerations, J. Geophys. Res.-Atmos., 94, 1849518514, 1989.

Balkanski, Y., Schulz, M., Claquin, T., and Guibert, S.: Reevaluation of Mineral aerosol radiative forcings suggests a better agreement with satellite and AERONET data, Atmos. Chem. Phys., 7, 81-95, doi:10.5194/acp-7-81-2007, 2007.

Balkanski, Y. J., Jacob, D. J., Gardner, G. M., Graustein, W. C., and Turekian, K. K.: Transport and residence times of tropospheric aerosols inferred from a global three-dimensional simulation of ${ }^{210} \mathrm{~Pb}$, J. Geophys. Res.-Atmos., 98, 20573-20586, doi:10.1029/93JD02456, 1993.

Bangert, M., Kottmeier, C., Vogel, B., and Vogel, H.: Regional scale effects of the aerosol cloud interaction simulated with an online coupled comprehensive chemistry model, Atmos. Chem. Phys., 11, 4411-4423, doi:10.5194/acp-11-4411-2011, 2011.

Barkan, J. and Alpert, P.: Synoptic patterns associated with dusty and non-dusty seasons in the Sahara, Theor. Appl. Climatol., 94, 153-162, doi:10.1007/s00704-007-0354-9, 2008.

Barnaba, F. and Gobbi, G. P.: Lidar estimation of tropospheric aerosol extinction, surface area and volume: Maritime and desert-dust cases, J. Geophys. Res.-Atmos., 106, 3005-3018, 2001.

Barnaba, F. and Gobbi, G. P.: Aerosol seasonal variability over the Mediterranean region and relative impact of maritime, continental and Saharan dust particles over the basin from MODIS data in the year 2001, Atmos. Chem. Phys., 4, 2367-2391, doi:10.5194/acp-4-2367-2004, 2004.

Barnaba, F., De Tomasi, F., Gobbi, G. P., Perrone, M. R., and Tafuro, A.: Extinction versus backscatter relationships for lidar applications at $351 \mathrm{~nm}$ : maritime and desert aerosol simulations and comparison with observations, Atmos. Res., 70, 229-259, 2004.

Barnaba, F., Bolignano, A., Di Liberto, L., Morelli, M., Lucarelli, F., Nava, S., Perrino, C., Canepari, S., Basart, S., Costabile, F., Dionisi, D., Ciampichetti, S., Sozzi, R., and Gobbi, G. P.: Desert dust contribution to $\mathrm{PM}_{10}$ levels in Italy: results from an automated method building on and upgrading the relevant European Commission Guidelines in support to the Air Quality Directive 2008/50/EC, Atmos. Environ., under review, 2017.
Basart, S., Dulac, F., Baldasano, J. M., Nabat, P., Mallet, M., Solmon, F., and Sic, B.: Extensive Comparison Between a Set of European Dust Regional Models and Observations in the Western Mediterranean for the Summer 2012 Pre-ChArMEx/TRAQA Campaign, in: Air Pollution Modeling and its Application XXIV, 79-83, Springer International Publishing, 2016.

Benjamin, S. G., Grell, G. A., Brown, J. M., Smirnova, T. G., and Bleck, R.: Mesoscale weather prediction with the RUC hybrid isentropic-terrain-following coordinate model, Mon. Weather Rev., 132, 473-494, 2004.

Bi, J., Huang, J., Fu, Q., Wang, X., Shi, J., Zhang, W., Huang, Z., and Zhang, B.: Toward characterization of the aerosol optical properties over Loess Plateau of Northwestern China, J. Quant. Spectrosc. Ra., 112, 346-360, 2011.

Bohren, C. F. and Huffman, D. R.: Absorption and scattering of light by small particles, Wiley, New York, 1983.

Chin, M., Rood, R. B., Lin, S.-J., Muller, J. F., and Thomspon, A. M.: Atmospheric sulfur cycle in the global model GOCART: Model description and global properties, J. Geophys. Res.-Atmos., 105, 24671-24687, 2000.

Chomette, O., Legrand, M., and Marticorena, B.: Determination of the wind speed threshold for the emission of desert dust using satellite remote sensing in the thermal infrared, J. Geophys. Res.Atmos., 104, 31207-31215, 1999.

Claquin, T., Schulz, M., Balkanski, Y., and Boucher, O.: Uncertainties in assessing radiative forcing by mineral dust, Tellus B, 50, 491-505, 1998.

D'Almeida, G. A.: A model for Saharan dust transport, J. Clim. Appl. Meteorol., 25, 903-916, 1986.

Dubovik, O. and King, M. D.: A flexible inversion algorithm for retrieval of aerosol optical properties from Sun and sky radiance measurements, J. Geophys. Res.-Atmos., 105, 20673-20696, 2000.

Dubovik, O., Smirnov, A., Holben, B. N., King, M. D., Kaufman, Y. J., Eck, T. F., and Slutsker, I.: Accuracy assessments of aerosol optical properties retrieved from AERONET sun and skyradiance measurements, J. Geophys. Res.-Atmos., 105, 97919806, 2000.

Dubovik, O., Sinyuk, A., Lapyonok, T., Holben, B. N., Mishchenko, M., Yang, P., Eck, T. F., Volten, H., Munoz, O., Veihelmann, B., an der Zande, W. J., Leon, J.-F., Sorokin, M., and Slutsker, I.: Applicatn of spheroid models to account for aerosol particle nonsphericity in remonte sensing of desert dust, J. Geophys. Res.Atmos., 111, D11208, doi:10.1029/2005JD006619, 2006.

EC: Directive 2008/50/EC of the European Parliament and of the Council of 21 May 2008 on ambient air quality and cleaner air for Europe, OJ L 152, 11 June 2008, 1-44, available at: http://eur-lex.europa.eu/LexUriServ/LexUriServ.do?uri= OJ:L:2008:152:0001:0044:EN:PDF (last access: 23 December 2016), 2008.

Eck, T. F., Holben, B. N., Reid, J. S., Dubovik, O., Smirnov, A., O'Neill, N. T., Slutsker, I., and Kinne, S.: Wavelength dependence of the optical depth of biomass burning, urban and desert dust aerosols, J. Geophys. Res.-Atmos., 104, 3133331350, 1999.

Engelstaedter, S., Tegen, I., and Washington, R.: North African dust emissions and transport, Earth-Sci. Rev., 79, 73-100, 2006.

Flentje, H., Heese, B., Reichardt, J., and Thomas, W.: Aerosol profiling using the ceilometer network of the German Meteo- 
rological Service, Atmos. Meas. Tech. Discuss., 3, 3643-3673, doi:10.5194/amtd-3-3643-2010, 2010a.

Flentje, H., Claude, H., Elste, T., Gilge, S., Köhler, U., PlassDülmer, C., Steinbrecht, W., Thomas, W., Werner, A., and Fricke, W.: The Eyjafjallajökull eruption in April 2010 - detection of volcanic plume using in-situ measurements, ozone sondes and lidar-ceilometer profiles, Atmos. Chem. Phys., 10, 10085-10092, doi:10.5194/acp-10-10085-2010, 2010b.

Fountoukis, C., Ackermann, L., Ayoub, M. A., Gladich, I., Hoehn, R. D., and Skillern, A.: Impact of atmospheric dust emission schemes on dust production and concentration over the Arabian Peninsula, Model. Earth Syst. Environ., 2, 1-6, 2016.

Freitas, S. R., Longo, K. M., Alonso, M. F., Pirre, M., Marecal, V., Grell, G., Stockler, R., Mello, R. F., and Sánchez Gácita, M.: PREP-CHEM-SRC - 1.0: a preprocessor of trace gas and aerosol emission fields for regional and global atmospheric chemistry models, Geosci. Model Dev., 4, 419-433, doi:10.5194/gmd-4419-2011, 2011.

Ghan, S. J. and Schwartz, S. E.: Aerosol properties and processes, B. Am. Meteorol. Soc., 88, p. 1059, 2007.

Ginoux, P., Prospero, J. M., Gill, T. E., Hsu, N. C., and Zhao, M.: Global-scale attribution of anthropogenic and natural dust sources and their emission rates based on MODIS Deep Blue aerosol products, Rev. Geophys., 50, RG3005, doi:10.1029/2012RG000388, 2012.

Grell, G. A., Peckham, S. E., Schmitz, R., McKeen, S. A., Frost, G., Skamarock, W. C., and Eder, B.: Fully coupled "online" chemistry within the WRF model, Atmos. Environ., 39, 6957-6976, 2005.

Gobbi, G. P.: Polarization lidar returns from aerosols and thin clouds: a framework for the analysis, Appl. Optics, 37, 55055508, 1998.

Gobbi, G. P., Barnaba, F., Giorgi, F., and Santacasa, A.: Altituderesolved properties of a Saharan dust event over the Mediterranean, Atmos. Environ., 34, 5119-5127, 2000.

Gobbi, G. P., Barnaba, F., Van Dingenen, R., Putaud, J. P., Mircea, M., and Facchini, M. C.: Lidar and in situ observations of continental and Saharan aerosol: closure analysis of particles optical and physical properties, Atmos. Chem. Phys., 3, 2161-2172, doi:10.5194/acp-3-2161-2003, 2003.

Gobbi, G. P., Barnaba, F., and Ammannato, L.: The vertical distribution of aerosols, Saharan dust and cirrus clouds in Rome (Italy) in the year 2001, Atmos. Chem. Phys., 4, 351-359, doi:10.5194/acp-4-351-2004, 2004.

Gobbi, G. P., Angelini, F., Barnaba, F., Costabile, F., Baldasano, J. M., Basart, S., Sozzi, R., and Bolignano, A.: Changes in particulate matter physical properties during Saharan advections over Rome (Italy): a four-year study, 2001-2004, Atmos. Chem. Phys., 13, 7395-7404, doi:10.5194/acp-13-7395-2013, 2013.

Gobbi, G. P., Barnaba, F., Basart, S., Bolignano, A., Costabile, F., Di Liberto, L., Dionisi, D., Drewnick, F., Lucarelli, F., Manigrasso, M., Perrino, C., Nava, S., Sauvage, L., Sozzi, R., Struckmeier, C., and Wille, H.: Specific Properties of Saharan Dust Advections to Italy: Main Outcomes of the DIAPASON Project, in preparation, 2017.

Goudie, A. S.: Dust storms: Recent developments, J. Environ. Manage., 90, 89-94, 2009.

Goudie, A. S. and Middleton, N. J.: Saharan dust storms: nature and consequences, Earth-Sci. Rev., 56, 179-204, 2001.
Haapanala, P., Räisänen, P., Kahnert, M., and Nousiainen, T.: Sensitivity of the shortwave radiative effect of dust on particle shape: Comparison of spheres and spheroids, J. Geophys. Res.-Atmos., 117, D08201, doi:10.1029/2011JD017216, 2012.

Holben, B. N., Eck, T. F., Slutsker, I., Tanre, D., Buis, J. P., Setzer, A., Vermote, E., Reagan, J. A., Kaufman, Y. J., Nakajima, T., and Lavenu, F.: AERONET - A federated instrument network and data archive for aerosol characterization, Remote Sens. Environ., 66, 1-16, 1998.

Hsu, N. C., Herman, J. R., Torres, O., Holben, B. N., Tanre, D., Eck, T. F., Smirnov, A., Chatenet, B., and Lavenu, F.: Comparisons of the TOMS aerosol index with Sun-photometer aerosol optical thickness: Results and applications, J. Geophys. Res.-Atmos., 104, 6269-6279, 1999.

Hsu, N. C., Tsay, S.-C., King, M. D., and Herman, J. R.: Aerosol properties over bright-reflecting source regions, Geoscience And Remote Sensing, IEEE T., 42, 557-569, doi:10.1109/TGRS.2004.824067, 2004.

Huang, J., Wang, T., Wang, W., Li, Z., and Yan, H.: Climate effects of dust aerosols over East Asian arid and semiarid regions, J. Geophys. Res.-Atmos., 119, 11398-11416, doi:10.1002/2014JD021796, 2014.

Huneeus, N., Schulz, M., Balkanski, Y., Griesfeller, J., Prospero, J., Kinne, S., Bauer, S., Boucher, O., Chin, M., Dentener, F., Diehl, T., Easter, R., Fillmore, D., Ghan, S., Ginoux, P., Grini, A., Horowitz, L., Koch, D., Krol, M. C., Landing, W., Liu, X., Mahowald, N., Miller, R., Morcrette, J.-J., Myhre, G., Penner, J., Perlwitz, J., Stier, P., Takemura, T., and Zender, C. S.: Global dust model intercomparison in AeroCom phase I, Atmos. Chem. Phys., 11, 7781-7816, doi:10.5194/acp-11-7781-2011, 2011.

IPCC: Climate Change 2001: The Scientific Basis. Contribution of Working Group I to the Third Assessment Report of the Intergovernmental Panel on Climate Change, edited by: Houghton, J. T., Ding, Y., Griggs, D. J., Noguer, M., van der Linden, P. J., Dai, X., Maskell, K., and Johnson, C. A., Cambridge University Press, Cambridge, United Kingdom and New York, NY, USA, 881 pp., 2001.

IPCC: Climate Change 2007: The Physical Science Basis. Contribution of Working Group I to the Fourth Assessment Report of the Intergovernmental Panel on Climate Change, edited by: Solomon, S., Qin, D., Manning, M., Chen, Z., Marquis, M., Averyt, K. B., Tignor, M., and Miller, H. L., Cambridge University Press, Cambridge, United Kingdom and New York, NY, USA, 2007.

Israelevich, P., Ganor, E., Alpert, P., Kishcha, P., and Stupp, A.: Predominant transport paths of Saharan dust over the Mediterranean Sea to Europe, J. Geophys. Res., 117, D02205, doi:10.1029/2011JD016482, 2012.

Kabatas, B., Unal, A., Pierce, R. B., Kindap, T., and Pozzoli, L.: The contribution of Saharan dust in $\mathrm{PM}_{10}$ concentration levels in Anatolian Peninsula of Turkey, Sci. Total Environ., 488, 413 421, 2014.

Kalashnikova, O. V. and Sokolik, I. N.: Importance of shapes and compositions of wind-blown dust particles for remote sensing at solar wavelengths, Geophys. Res. Lett., 29, 1398, doi:10.1029/2002GL014947, 2002.

Kalnay, E., Kanamitsu, M., Kistler, R., Collins, W., Deaven, D., Gandin, L., Iredell, M., Saha, S., White, G., Woollen, J., and 
Zhu, Y.: The NCEP/NCAR 40-year reanalysis project, B. Am. Meteorol. Soc., 77, 437-471, 1996.

Kang, J. Y., Yoon, S. C., Shao, Y., and Kim, S. W.: Comparison of vertical dust flux by implementing three dust emission schemes in WRF/Chem, J. Geophys. Res.-Atmos., 116, D09202, doi:10.1029/2010JD014649, 2011.

Karydis, V. A., Kumar, P., Barahona, D., Sokolik, I. N., and Nenes, A.: On the effect of dust particles on global cloud condensation nuclei and cloud droplet number, J. Geophys. Res.-Atmos., 116, D23204, doi:10.1029/2011JD016283, 2011.

Kaskaoutis, D. G., Kosmopoulos, P. G., Nastos, P. T., Kambezidis, H. D., Sharma, M., and Mehdi, W.: Transport pathways of Sahara dust over Athens, Greece as detected by MODIS and TOMS. Geomatics, Natural Hazards and Risk, 3, 35-54, 2012.

Kaufman, Y. J., Tanré, D., Remer, L. A., Vermote, E., Chu, A., and Holben, B. N.: Operational remote sensing of tropospheric aerosol over land from EOS Moderate Resolution Imaging Spectroradiometer, J. Geophys. Res.-Atmos., 102, 17051-17067, 1997.

Klett, J. D.: Stable analytical inversion solution for processing lidar returns, Appl. Optics, 20, 211-220, 1981.

Klose, M. and Shao, Y.: Stochastic parameterization of dust emission and application to convective atmospheric conditions, Atmos. Chem. Phys., 12, 7309-7320, doi:10.5194/acp-12-73092012, 2012.

Knippertz, P. and Todd, M. C.: Mineral dust aerosols over the Sahara: Meteorological controls on emission and transport and implications for modeling, Rev. Geophys., 50, RG1007, doi:10.1029/2011RG000362, 2012.

Levy, R., Remer, L., and Dubovik, O.: Global aerosol optical properties and application to Moderate Resolution Imaging Spectroradiometer aerosol retrieval over land, J. Geophys. Res.-Atmos., 112, D13210, doi:10.1029/2006JD007815, 2007a.

Levy, R., Remer, L., Mattoo, S., Vermote, E., and Kaufman, Y. J.: Second-generation operational algorithm: Retrieval of aerosol properties over land from inversion of Moderate Resolution Imaging Spectroradiometer spectral reflectance, J. Geophys. Res.-Atmos., 112, D13211, doi:10.1029/2006JD007811, 2007b.

Levy, R. C., Mattoo, S., Munchak, L. A., Remer, L. A., Sayer, A. M., Patadia, F., and Hsu, N. C.: The Collection 6 MODIS aerosol products over land and ocean, Atmos. Meas. Tech., 6, 29893034, doi:10.5194/amt-6-2989-2013, 2013.

Lin, Y. L., Farley, R. D., and Orville, H. D.: Bulk parameterization of the snow field in a cloud model, J. Clim. Appl. Meteorol., 22, 1065-1092, 1983.

Mallone, S., Stafoggia, M., Faustini, A., Gobbi, G. P., Marconi, A., and Forastiere, F.: Saharan dust and associations between particulate matter and daily mortality in Rome, Italy, Environ. Health Persp., 119, 1409-1414, 2011.

Marticorena, B. and Bergametti, G.: Modeling the atmospheric dust cycle: 1. Design of a soil-derived dust emission scheme, J. Geophys. Res.-Atmos., 100, 16415-16430, 1995.

Mlawer, E. J., Taubman, S. J., Brown, P. D., Iacono, M. J., and Clough, S. A.: Radiative transfer for inhomogeneous atmospheres: RRTM, a validated correlated-k model for the longwave, J. Geophys. Res.-Atmos., 102, 16663-16682, 1997.

Molesworth, A. M., Cuevas, L. E., Connor, S. J., Morse, A. P., and Thomson, M. C.: Environmental risk and meningitis epidemics in Africa, Emerg. Infect Dis., 9, 1287-1293, 2003.
Moulin, C., Lambert, C. E., Dayan, U., Masson, V., Ramonet, M., Bousquet, P., Legrand, M., Balkanski, Y. J., Guelle, W., Marticorena, B., Bergametti, G., and Dulac, F.: Satellite climatology of African dust transport in the Mediterranean atmosphere, J. Geophys. Res.-Atmos., 103, 13137-13144, 1998.

Nakanishi, M. and Niino, H.: Development of an improved turbulence closure model for the atmospheric boundary layer, J. Meteorol. Soc. Jpn., 87.5, 895-912, 2009.

Paulson, C. A.: The mathematical representation of wind speed and temperature profiles in the unstable atmospheric surface layer, J. Clim. Appl. Meteorol., 9, 857-861, 1970.

Pey, J., Querol, X., Alastuey, A., Forastiere, F., and Stafoggia, M.: African dust outbreaks over the Mediterranean Basin during 2001-2011: $\mathrm{PM}_{10}$ concentrations, phenomenology and trends, and its relation with synoptic and mesoscale meteorology, Atmos. Chem. Phys., 13, 1395-1410, doi:10.5194/acp-13-13952013, 2013.

Prospero, J. M. and Mayol-Bracero, O. L.: Understanding the transport and impact of African dust on the Caribbean basin, B. Am. Meteorol. Soc., 94, 1329-1337, 2013.

Querol, X., Pey, J., Pandolfi, M., Alastuey, A., Cusack, M., Pérez, N., Moreno, T., Viana, M., Mihalopoulos, N., Kallos, G., and Kleanthous, S.: African dust contributions to mean ambient $\mathrm{PM}_{10}$ mass-levels across the Mediterranean Basin, Atmos. Environ., 43, 4266-4277, 2009.

Remer, L. A., Kaufman, Y. J., Tanre, D., Mattoo, S., Chu, D. A., Martins, J. V., Li, R. R., Ichoku, C., Levy, R. C., Kleidman, R. G., Eck, T. F., Vermote, E., and Holben, B. N.: The MODIS aerosol algorithm, products, and validation, J. Atmos. Sci., 62, 947-973, doi:10.1175/JAS3385.1, 2005.

Rizza, U., Anabor, V., Mangia, C., Miglietta, M. M., Degrazia, G. A., and Passerini, G.: WRF-Chem Simulation of a saharan dust outbreak over the mediterranean regions, Vol. 38, Special Edition, 330-336, Ciência e Natura, doi:10.5902/2179460X20249, 2016.

Rosenfeld, D., Rudich, Y., and Lahav, R.: Desert dust suppressing precipitation: A possible desertification feedback loop, P. Natl. Acad. Sci. USA, 98, 5975-5980, 2001.

Rutledge, S. A. and Hobbs, P. V.: The mesoscale and microscale structure and organization of clouds and precipitation in midlatitude cyclones. XII: A diagnostic modeling study of precipitation development in narrow cold-frontal rainbands, J. Atmos. Sci., 41, 2949-2972, 1984.

Salomonson, V. V., Barnes, W. L., Maymon, P. W., Montgomery, H. E., and Ostrow, H.: MODIS: Advanced facility instrument for studies of the Earth as a system, IEEE T. Geosci. Remote, 27, 145-153, 1989.

Salvador, P., Alonso-Pérez, S., Pey, J., Artíñano, B., de Bustos, J. J., Alastuey, A., and Querol, X.: African dust outbreaks over the western Mediterranean Basin: 11-year characterization of atmospheric circulation patterns and dust source areas, Atmos. Chem. Phys., 14, 6759-6775, doi:10.5194/acp-14-6759-2014, 2014.

Schepanski, K., Tegen, I., and Macke, A.: Comparison of satellite based observations of Saharan dust source areas, Remote Sens. Environ., 123, 90-97, doi:10.1016/j.rse.2012.03.019, 2012.

Schulz, M., Chin, M., and Kinne, S.: The Aerosol Model Comparison Project, AeroCom, Phase II: Clearing up diversity, IGAC Newsl., 41, 2-11, 2009. 
Seinfeld, J. H. and Pandis, S. N.: Chemistry of the atmospheric aqueous phase, Atmospheric Chemistry and Physics: From Air Pollution to Climate Change, 337-407, John Wiley \& Sons, Inc., Hoboken, New Jersey, 1998.

Shao, Y.: A model for mineral dust emission, J. Geophys. Res.Atmos., 106, 20239-20254, doi:10.1029/2001JD900171, 2001.

Shao, Y.: Simplification of a dust emission scheme and comparison with data, J. Geophys. Res.-Atmos., 109, D10202, doi:10.1029/2003JD004372, 2004.

Shao, Y., Ishizuka, M., Mikami, M., and Leys, J. F.: Parameterization of size-resolved dust emission and validation with measurements, J. Geophys. Res., 116, D08203, doi:10.1029/2010JD014527, 2011a.

Shao, Y., Wyrwoll, K. H., Chappell, A., Huang, J., Lin, Z., McTainsh, G. H., Mikami, M., Tanaka, T. Y., Wang, X., and Yoon, S.: Dust cycle: An emerging core theme in Earth system science, Aeolian Res., 2, 181-204, 2011 b.

Sokolik, I. N. and Toon, O. B.: Incorporation of mineralogical composition into models of the radiative properties of mineral aerosol from UV to IR wavelengths, J. Geophys. Res.-Atmos., 104, 9423-9444, 1999.

Stafoggia, M., Zauli-Sajani, S., Pey, J., Samoli, E., Alessandrini, E., Basagaña, X., Cernigliaro, A., Chiusolo, M., Demaria, M., Díaz, J., Faustini, A., Katsouyanni, K., Kelessis, A. G., Linares, C., Marchesi, S., Medina, S., Pandolfi, P., Pérez, N., Querol, X., Randi, G., Ranzi, A., Tobias, A., and Forastiere, F.: MEDPARTICLES Study Group, Desert dust outbreaks in Southern Europe: contribution to daily $\mathrm{PM}_{10}$ concentrations and shortterm associations with mortality and hospital admissions, Environ Health Persp., 124, 413-419, doi:10.1289/ehp.1409164, 2016.

Struckmeier, C., Drewnick, F., Fachinger, F., Gobbi, G. P., and Borrmann, S.: Atmospheric aerosols in Rome, Italy: sources, dynamics and spatial variations during two seasons, Atmos. Chem. Phys., 16, 15277-15299, doi:10.5194/acp-16-152772016, 2016
Su, L. and Fung, J. C. H.: Sensitivities of WRF-Chem to dust emission schemes and land surface properties in simulating dust cycles during springtime over East Asia, J. Geophys. Res.-Atmos., 120, 11215-11230, doi:10.1002/2015JD023446, 2015.

Tao, W. K., Simpson, J., and McCumber, M.: An ice-water saturation adjustment, Mon. Weather Rev., 117, 231-235, 1989.

Tsarpalis, K., Papadopoulos, A., and Katsafados, P.: The Implementation of a Dust Wet Deposition Scheme in the WRFCHEM Model, Perspectives on Atmospheric Sciences, Part I, 69-74, edited by: Karacostas, T., Bais, A., and Nastos, P. T., Springer International Publishing, doi:10.1007/978-3-31935095-0_10, 2017.

Wang, W., Huang, J., Minnis, P., Hu, Y., Li, J., Huang, Z., Ayers, J. K., and Wang, T.: Dusty cloud properties and radiative forcing over dust source and downwind regions derived from A-Train data during the Pacific Dust Experiment, J. Geophys. Res., 115, D00H35, doi:10.1029/2010JD014109, 2010

Wesely, M. L.: Parameterization of surface resistances to gaseous dry deposition in regional-scale numerical models, Atmos. Environ., 41, S52-S63, 1989.

Wiegner, M. and Geiß, A.: Aerosol profiling with the Jenoptik ceilometer CHM15kx, Atmos. Meas. Tech., 5, 1953-1964, doi:10.5194/amt-5-1953-2012, 2012.

Yu, H., Chin, M., Bian, H., Yuan, T., Prospero, J. M., Omar, A. H., and Remer, L. A.: Quantification of trans-Atlantic dust transport from seven-year (2007-2013) record of CALIPSO lidar measurements, Remote Sens. Environ., 159, 232-249, 2015. 